\title{
Interdisciplinary Reservoir Management-A Tool for Sustainable Water Resources Management
}

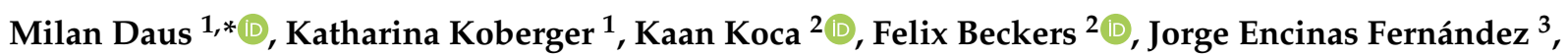 \\ Barbara Weisbrod ${ }^{4}$, Daniel Dietrich ${ }^{4}{ }^{(\mathbb{C}}$, Sabine Ulrike Gerbersdorf ${ }^{2}$, Rüdiger Glaser ${ }^{1}\left(\mathbb{D}\right.$, Stefan Haun ${ }^{2}{ }^{(D)}$, \\ Hilmar Hofmann ${ }^{3}$, Dominik Martin-Creuzburg ${ }^{3}{ }^{-0}$, Frank Peeters $^{3}$ and Silke Wieprecht ${ }^{2}$
}

1 Physical Geography, Albert-Ludwigs-University Freiburg, Schreiberstrasse 20, 79098 Freiburg, Germany; katharina-koberger@gmx.de (K.K.); ruediger.glaser@geographie.uni-freiburg.de (R.G.)

2 Institute for Modelling Hydraulic and Environmental Systems, University of Stuttgart, Pfaffenwaldring 61, 70569 Stuttgart, Germany; kaan.koca@iws.uni-stuttgart.de (K.K.); felix.beckers@iws.uni-stuttgart.de (F.B.); sabine.gerbersdorf@mwk.bwl.de (S.U.G.); stefan.haun@iws.uni-stuttgart.de (S.H.); silke.wieprecht@iws.uni-stuttgart.de (S.W.)

3 Limnological Institute, University of Konstanz, Mainaustraße 252, 78464 Konstanz, Germany; jorge.encinas@gmail.com (J.E.F.); hilmar.hofmann@uni-konstanz.de (H.H.); dominik.martin-creuzburg@uni-konstanz.de (D.M.-C.); Frank.Peeters@uni-konstanz.de (F.P.)

4 Human and Environmental Toxicology, University of Konstanz, Universitätsstrasse 10, 78464 Konstanz, Germany; barbara.weisbrod@uni-konstanz.de (B.W.); daniel.dietrich@uni-konstanz.de (D.D.)

Citation: Daus, M.; Koberger, K.; Koca, K.; Beckers, F.; Encinas Fernández, J.; Weisbrod, B.; Dietrich,

D.; Gerbersdorf, S.U.; Glaser, R.; Haun, S.; et al. Interdisciplinary Reservoir Management-A Tool for Sustainable Water Resources Management. Sustainability 2021, 13, 4498. https://doi.org/10.3390/ su13084498

Academic Editor: Konstantinos Stefanidis

Received: 18 March 2021

Accepted: 10 April 2021

Published: 18 April 2021

Publisher's Note: MDPI stays neutral with regard to jurisdictional claims in published maps and institutional affiliations.

Copyright: (c) 2021 by the authors. Licensee MDPI, Basel, Switzerland. This article is an open access article distributed under the terms and conditions of the Creative Commons Attribution (CC BY) license (https:// creativecommons.org/licenses/by/ $4.0 /)$.

Abstract: Reservoirs are a common way to store and retain water serving for a multitude of purposes like storage of drinking and irrigation water, recreation, flood protection, navigation, and hydropower production, and have been built since centuries. Today, few reservoirs serve only one purpose, which requires management of present demands and interests. Since each reservoir project will cause negative impacts alongside desired advantages both on a local, regional and global scale, it is even more urgent to develop a common management framework in an attempt to mitigate negative impacts, incorporate different demands and make them visible within the discourse in order to avoid conflicts from early on. The scientific publications on reservoirs are manifold, yet a comprehensive and integrative holistic tool about management of this infrastructure is not available. Therefore, a comprehensive and integrated conceptual tool was developed and proposed by the authors of this paper that can contribute to the sustainable management of existing reservoirs. The tool presented herein is based on the results from the interdisciplinary CHARM (CHAllenges of Reservoir Management) project as well as the condensed outcome of relevant literature to aid and enhance knowledge of reservoir management. The incorporated results are based on field, laboratory and empirical social research. The project CHARM focused on five different aspects related to existing reservoirs in southern Germany (Schwarzenbachtalsperre, Franconian Lake District), namely: sedimentation of reservoirs, biostabilisation of fine sediments, toxic cyanobacteria(l) (blooms), greenhouse gas emissions from reservoirs and social contestation, respectively consent. These five research foci contributed to the topics and setup of a conceptual tool, put together by the research consortium via delphi questioning, which can be found alongside this publication to provide insights for experts and laymen. Conceptualising and analysing the management in combination with quantitative and qualitative data in one descriptive tool presents a novelty for the case studies and area of research. The distribution within the scientific community and interested public will possibly make a positive contribution to the goal of sustainable water resources management in the future.

Keywords: reservoir management; sediments; biofilm; cyanobacteria; greenhouse gas emissions; societal implications 


\section{Introduction}

Water and energy are two of the most important resources on our planet. Dams and reservoirs provide and store both resources based on the implementation of infrastructure to retain water. Due to population growth and changes in lifestyle the demands on water bodies are constantly rising and diversifying [1]. This incorporates interests like drinking and irrigation water supply, flood protection, energy production or navigation [2]. It is estimated that around 58,000 large dams are built, planned or under construction worldwide, a trend which will likely accelerate in the future [3]. In Germany, dam construction with an emphasis on hydropower began around 1900 and reached its peak during the second half of the last century [4]. At present, there are 371 reservoirs that meet the ICOLD (International Commission on Large Dams) definition of large dams (more than $15 \mathrm{~m}$ dam height or 3 million $\mathrm{m}^{3}$ storage capacity) [5]. The construction of dams and reservoirs does not only radically change the area directly affected by the artificial lake itself, but the entire runoff system as well as large parts of the catchment area [6]. It will cause changes in the flow and sediment regime, leading to sediment deposition in reservoirs, accumulations of nutrients in the impounded water body, that may foster cyanobacterial blooms as well as methane and carbon dioxide emissions, and possibly lead to conflict in the local communities to name just a few impacts within the close surrounding of the reservoir [7]. These issues in reservoir management have motivated the project team of CHARM (CHAllenges of Reservoir Management) with a consortium comprised of the universities Stuttgart, Konstanz and Freiburg in Baden-Wuerttemberg (Germany) to explore these challenges and positively contribute to future demands regarding managing (large) water reservoirs.

Figure 1 displays some of the environmental, social and managerial factors, influencing the stakeholders and elements involved in obtaining reservoir management strategies and vice versa. The connection of the environmental and social setup displays the stakeholders as environmental, technical and/or social entities profit or be adversely affected by the individual reservoir projects. These influences occur on different scales, such as time, space and social values $[8,9]$ and therefore it is essential to get a comprehensive overview of the field and it's interactions. Water resources management is an approach to fulfil the social/environmental needs as well as the technical requirements in operating reservoirs. Water resources management gained scientific attention in the past decades, due to worldwide growing demands in respect to (fresh)water and energy [10]. As management of these resources always affects a multitude of implications from technical, legal and environmental, to social values, norms and habits and is vice versa affected by them, a holistic approach to meet the demands is imperative for management of freshwater resources.

Previous studies prove that reservoir management is of central importance for the sustainable use of water and energy resources. The focus of the individual study is the crucial question, targeting very different aspects and focusing on very different projects in diverse regions of the world. Many studies focus on the effects and trade-offs of reservoir operation to provide best practice solutions for managerial questions around the natural environment e.g., water, sediment and nutrient/pollutant management [11-18]. Other foci are the governance and social spheres in water resources research. Questions about these implications are well interwoven with the national and international context the reservoirs are situated in. Theory and best practice in this manner were being established in studies focusing on governmental and social implications [19-27]. Mathematical modelling, to provide optimal decision making support in water management resources [28,29], was also being studied with stochastic approaches [30]. Bringing together these two worlds of the natural and social environment and therefore bridging a gap in management related questions is discussed in other publications [31,32], fostering sustainable water resources management, also under climate and demographic change scenarios [33]. 


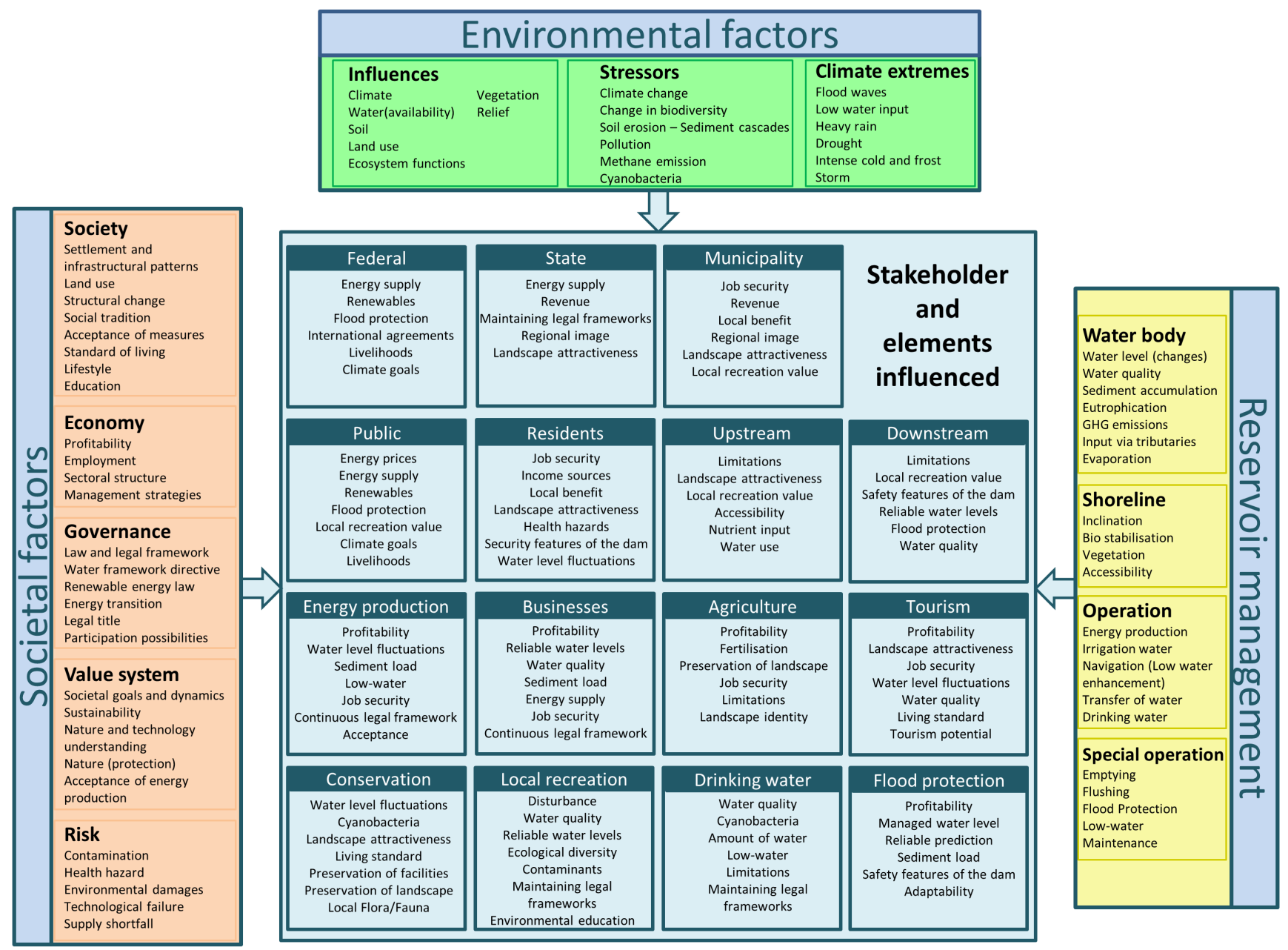

Figure 1. Complex interactions of the triangle societal factors-environmental factors-reservoir management, leading to a multi stakeholder involvement in obtaining a sustainable reservoir management.

The important topic of reservoir management was a motivation for initialising the project CHARM to bring together different disciplines and find best practice solutions for challenges in reservoir management in a central European context. As the initial and future challenges connected to reservoirs will likely rise with increasing numbers of dams worldwide, the interdisciplinary project of CHARM made an effort to increase knowledge in the issues that tangent management questions in the German, or central European context. These efforts are summarised in this publication, to foster the interdisciplinary knowledge on reservoir management and to transport best practice information to the public. Section 3 will provide an overview of implications and management strategies of the five research foci in the CHARM project. For accessing the tool, which presents a novelty in incorporating the different expertise from engineering, natural science and geography in a case study perspective from Germany, see Section 4 . This descriptive tool will allow interested readers to get to know implications of reservoir management from a holistic point of view, enabling the management to meet important requirements in the water resources sector. This publication is indexed in five main sections. First the materials and methods will be displayed in Section 2. Secondly a closer look into the information gathered through literature review and the outcome of the interdisciplinary research project CHARM can be found in Section 3. The interdisciplinary tool will be discussed in Section 4 and finally an outlook is given in Section 5. 


\section{Materials and Methods}

The approach to summarise and condense information on the management of reservoirs is deeply connected to the interdisciplinary CHARM projects results. Published experimental, field and model results were being integrated, alongside best practice solutions from literature, into an conceptual tool (see Section 4). The core of this descriptive tool is a matrix with the most common implications of management at the reservoirs investigated in the CHARM project. This matrix was put together using a delphi approach $[34,35]$ by members of the team and other experts in the fields of research: engineering, biology, environmental physics and geography. As the delphi technique is a qualitative method, the tool can give information on the topics chosen by the expert board with emphasis on a general overview in reservoir management implications. To access and download the tool and the accompanying, interactive, list of literature see: https://github.com/milan-daus/Literature-on-Water-Reservoir-Management. The matrix combination and cross influences are derived from a cross-impact matrix approach [36]. As the cross-impact matrix is of descriptive nature, the individual cells will be highlighted via a distinct sequence of characters by the user, enabling automated colour coding and hence a quick overview. To guarantee dissemination of the results, foster long term information, and keep the tool accessible, we choose to provide a link to the internet portal Github. The results incorporated in the tool were derived from the five year interdisciplinary research project and stem mainly from the case studies of Schwarzenbachtalsperre (SBT) and Franconian Lake District (FLD) with Lake Altmuehl, Small/Large Lake Brombach, Lake Igelsbach and Lake Roth in Germany see Figure 2.

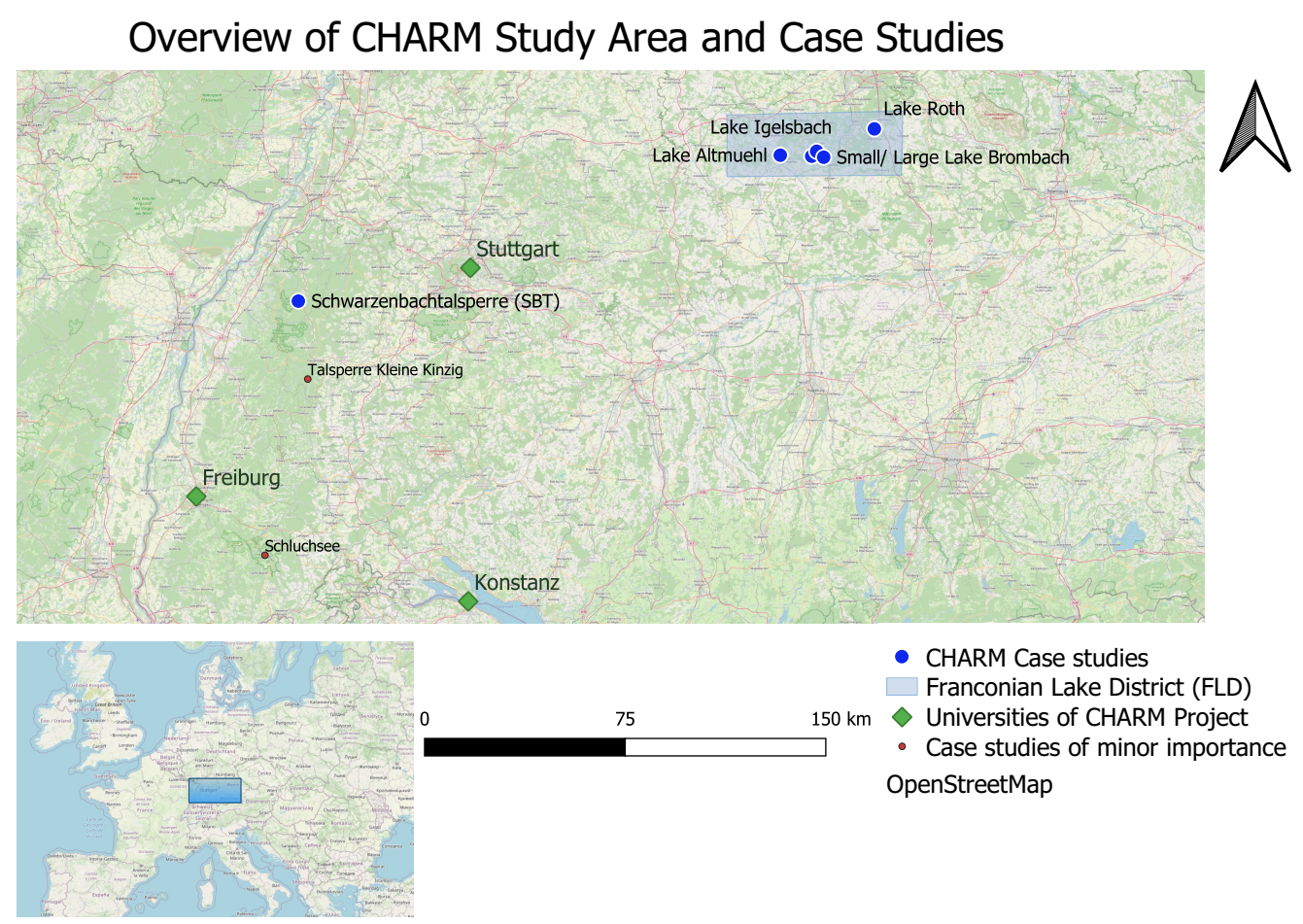

Figure 2. Overview on the location of the CHARM host institutions and the studied areas, located in southern Germany.

These reservoirs serve for very different purposes, where the SBT is a pumped storage hydropower reservoir and the FLD is a water transferring project. Other case studies, which were of minor importance in the course of the CHARM project are the Talsperre Kleine Kinzig as a drinking water reservoir and the Schluchsee as a larger pumped hydropower reservoir, both located in the Black Forest. Hence, the allocation of field data had to incorporate many aspects from sediment sampling, over nutrient analysis and gas flows, laboratory analysis, to data about the catchment and social surroundings with land use 
and land cover change analysis, media analysis of newspaper articles, expert interviews and surveys. The information taken from literature for best practice solutions were derived in a qualitative process analogue to the results of the project. The multi-layered approach was chosen to gain a maximum of knowledge for the integration into the tool, see Figure 3.

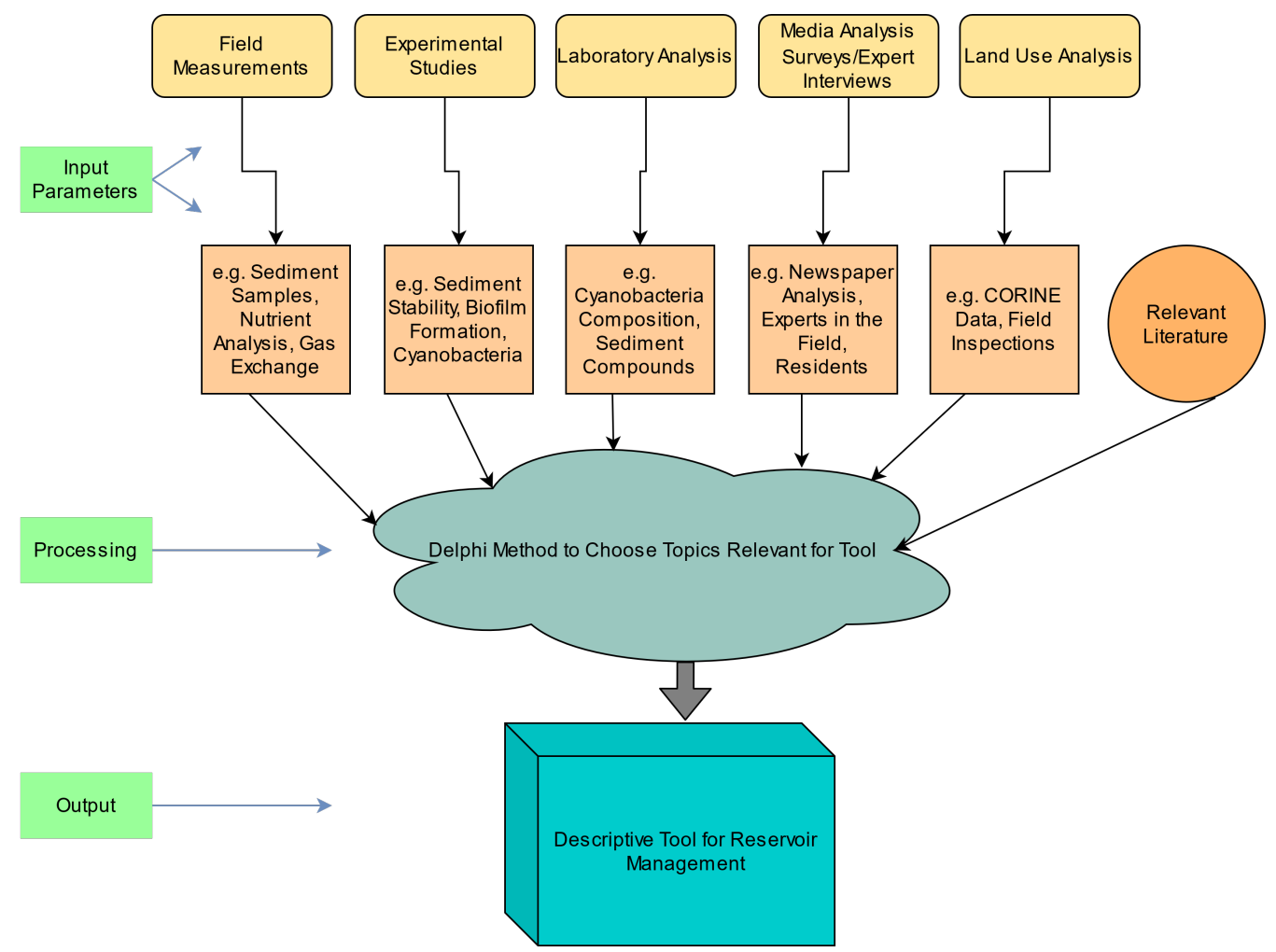

Figure 3. Conceptualising approach in obtaining, analysing and condensing information into a descriptive tool.

The concept allows users to inform themselves about the results and, if interested and desired, to expand the tool as such with their own focal points and findings. This will contribute to sum up core findings and future prospects in the field of reservoir management. The next section will provide an overview of condensed implications by topic of the individual work packages (WP) of the CHARM project.

\section{Results of Condensed Literature Information in Combination with the Interdisciplinary CHARM Project Findings}

As the goal of the approach is to give a holistic overview about implications of reservoirs and their management, this section will provide information on the results of the project and the synopsis of best practice from literature, which will be ordered as follows: First, the implications and management options of sediment will be highlighted by WP 1 from University of Stuttgart (Section 3.1). Secondly, a closer look into the implications of biostabilisation is undertaken from WP 2 from University of Stuttgart (Section 3.2). Thirdly, the causes, occurrences and consequences of cyanobacteria are addressed by WP 3 from University of Konstanz (Section 3.3). Fourthly, greenhouse gas emissions from reservoirs are described by WP 4 from University of Konstanz (Section 3.4). Fifthly, the societal implications of reservoir management are summarised by WP 5 from University of Freiburg (Section 3.5). Figure 4 displays a simplified model of topics under research and collaboration in between the different WP's. Since the research areas around reservoirs are quite diverse, this report will not be able to include all implications. The focus is rather on bringing together different disciplines and topics, to create a holistic foundation as a basis for an overview on management of reservoirs in a comprehensive tool for identification of (future) challenges. As the Figure 4 displays the interactions of the processes within and 
around a model reservoir, the WP's addressed the different aspects with interdisciplinary approaches. This in mind, the topics researched are often well connected within and around the reservoir from water entering, to the water that leaves the reservoir. This incorporates sediment and nutrient fluxes, greenhouse gas emissions and influences on the carbon cycle of the artificial water body. The arrows represent direct water flows (black), biotic interactions (green) and sediment/nutrient and gas fluxes (grey).

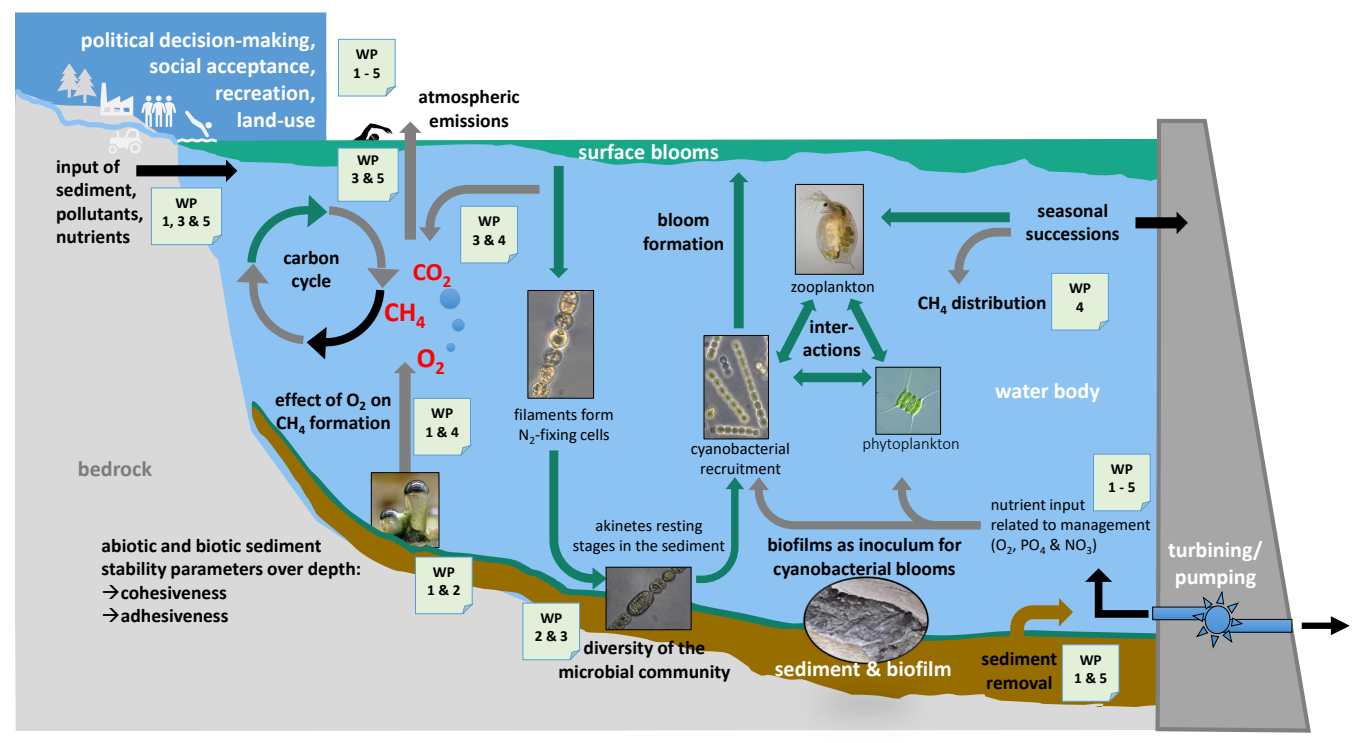

Figure 4. CHARM research project topics and collaboration between the single WP's in a model reservoir; modified after: [7].

\subsection{Sediments}

The global construction of approx. 58,000 large dams [3,37], has considerably influenced the delivery of sediment from land to the oceans by fragmenting the river network [38], resulting in an estimate of over $100 \mathrm{Gt}$ sediment being trapped in reservoirs on a global scale [39]. When a river enters a reservoir, sediments carried by the river settle due to decreasing flow velocities and turbulence levels. Consequently, sedimentation reduces reservoir storage capacity that was designed for storing water and thus reduces the services provided by the reservoirs. Several parameters influence the quantity of settled sediments in the reservoir, such as catchment specific, reservoir specific and sedimentological parameters. Although the sedimentation process depends strongly on the above mentioned parameters, reservoir sedimentation itself follows generally a pre-defined pattern, where coarser sediments settle first and finer sediments are further transported into the reservoir [40-42]. Especially fine sediments with cohesive properties should be considered when it is intended to obtain a sustainable reservoir management. The reason for the latter are that erosion, transport, deposition and consolidation (ETDC) of cohesive sediments are complex processes since physical, chemical, and biological parameters are involved (e.g., [42-49]). Due to the binding properties of fine sediments (large surfaces compared to their volume) coupled with biostabilisation (see Section 3.2), pollutants, nutrients and organic matter also accumulate in the reservoirs [50,51] impairing water quality (see Section 3.3) and leading to production and emission of $\mathrm{CO}_{2}$ and $\mathrm{CH}_{4}$ (see Section 3.4). Since the quantities of in- and outflowing sediments are different, morphology and ecology of downstream channels are also negatively impacted [52-57]. It is estimated that approximately $40 \%$ of the global river discharge is intercepted by large reservoirs with a storage capacity larger than $0.5 \mathrm{~km}^{3}$, yielding an estimation of $4-5 \mathrm{Gt}$ sediments being trapped in reservoirs annually [58-60] estimate a reservoir storage reduction by $1 \%$ per year worldwide on average. Coupling this information with current storage of major dams $\left(6863.5 \mathrm{~km}^{3}\right)$ and assuming a dry bulk density of $1200 \mathrm{~kg} / \mathrm{m}^{3}$, an annual storage loss is 
calculated to be $\sim 82 \mathrm{Gt} / \mathrm{yr}$, supporting the estimation of [39] rather than the estimation given by [57]. It must, however, be noted that storage loss is not equally distributed around the world since the quantity of sediments deposited in reservoirs depends strongly on the boundaries of the catchment and the reservoir itself [42]. In addition, hydrological variability as a result of climate change [61-63] and human interactions such as land clearance may also increase soil erosion and subsequently sediment loads in rivers, leading to increased reservoir sedimentation. Therefore, development and implementation of sustainable sediment management techniques to maintain sufficient reservoir storage on a long term has become increasingly important in meeting rising water and energy demands (e.g., [2,64]). Traditionally, reservoirs are designed for a lifetime of 50 to 100 years [41,65], leading to societal, environmental and economical problems beyond the designed lifetime. Often the dead storage volume accounts for sedimentation. However, depending on the given boundaries, reservoir sedimentation may claim more volume than the designed dead storage volume provides and so regulative reservoir management becomes necessary to mitigate sedimentation. Indeed, based on the estimated $\sim 69 \mathrm{~km}^{3}$ annual storage loss, $30 \%$ and $80 \%$ of the global reservoir capacity will be lost by 2050 and 2100, respectively, in case the reservoirs are managed ineffectively. Therefore, it is crucial that sediment management strategies and potential required facilities are already considered during the design and construction phase of new reservoirs to address reservoir sedimentation from early on. This will ensure that implemented measures are most effective for long-term periods ( $>100$ years). This is particularly required with regard to competing land uses as well as pushing social (see Section 3.5) and environmental issues. Furthermore, existing reservoirs must be adapted to sustainable management practices inasmuch as it is possible [65]. This is why in the 1990s several guidelines relating to sediment management in reservoirs have been released (e.g., [41,41,66-68]). These documents provide specific standards to evaluate the feasibility of different sediment management strategies [69-71]. As each reservoir is unique, decisions on appropriate management strategies must be selected with care. In addition to guiding documents, containing empirical and analytical approaches, also physical models are employed to simulate management strategies. Recently, numerical models have been frequently employed to evaluate the success of sediment management strategies $[40,48,64,72-76]$. Sediment management strategies to reduce reservoir sedimentation and maintain reservoir volume can be summarized under three main approaches [67]:

- reducing the sediment yield originating from the catchment by controlling erosion upstream

- minimizing the sediment depositions in the reservoir by managing flows during periods of high flows

- recovering already lost reservoir volume by removing deposited sediment applying various techniques

\subsection{Biostabilisation of Fine Sediments}

The predominant microbial lifestyle in aquatic ecosystems is characterised by multicellular and multispecies communities [77-80], flourishing between their self-synthesised three-dimensional matrix of extracellular polymeric substances (EPS) $[78,81]$. These diverse microbial communities are capable of colonising various solid-water interfaces, with sediment being excellent substrata $[82,83]$ and possess common features that distinguish them as biofilm $[78,83,84]$. The transition of microorganisms from planktonic to biofilm lifestyle is controlled by a range of environmental conditions among which the local hydrodynamics are of paramount importance $[83,85]$. Surface-attached microorganisms deactivate the expression of the genes involved in motility and activate the genes involved in adhesion and biofilm development [86]. Surface association and subsequent biofilm formation provides these microorganisms with critical advantages. As opposed to a single planktonic lifestyle, enhanced availability of essential nutritional resources, increased interactions of microorganisms within the surface associated biofilm-matrix and distinct, mostly diverse compositions lead to higher metabolic activity. This results in high survival, wide tolerance 
to environmental conditions and higher reproduction potential to the embedded microorganisms [78,87]. The community composition and productivity of the microorganisms are continuously controlled by various reciprocal interactions between chemical, biological and physical (e.g., hydrological) factors [83]. The operation of reservoirs can lead to significant accumulations of fine sediment and nutrients, which can result in formation and development of biofilms on the sediment surface. Microorganisms and their metabolic activities support fundamental ecological and biochemical processes, e.g., biodegradation of organic matter and toxins, water self-purification and the cycling of nutrients [82,88-91] and the community composition eventually determines their ecological and environmental functions [92-94]. The microorganisms settled on fine sediments are also known to glue sediment grains together through an EPS matrix $[95,96]$ and permeate their void space, which can, in turn, alter sediment properties, e.g., density, morphology, size gradation, architecture [97-100], erosion and transport behaviour of sediments [44,101-109] and associated contaminants $[110,111]$. The ability of biofilms to increase erosion thresholds by biological actions is named "biostabilisation" $[96,112,113]$ and has been reported to mediate the cycle of sediment erosion, transportation, deposition and consolidation (ETDC) in aquatic ecosystems, including reservoirs [105]. Although the importance of biostabilisation at the sediment surface and deeper layers has been increasingly recognised through laboratory and field studies [96,102] (and references therein) over the past two decades, yet little is known about the transport processes of biofilm-bound sediment and its effect on aquatic environment and bed morphology [114]. Thus, sediment transport models as well as river and reservoir management strategies disregard and therefore underestimate the effect of biofilm growth on sediment.

\subsection{Cyanobacteria}

Reservoirs and dams used for hydropower or drinking water supply are subject to major anthropogenic and environmental influences, potentially favouring cyanobacterial harmful algal blooms (cHABs). Pelagic and benthic cyanobacteria are known to produce a large variety of toxins (e.g., microcystins, saxitoxins, anatoxins), frequently resulting in human and animal poisoning events [115]. There is consensus that increased nutrient input (eutrophication) in conjunction with increasing surface water temperatures promoting water column stratification, are closely linked to more frequent and pronounced cHABs [116-118]. Nutrients that have been mainly linked to the occurrence of eutrophication associated $\mathrm{cHABs}$ are phosphorus $(\mathrm{P})$ and nitrogen $(\mathrm{N})$. However, past decades of research revealed that blooms are not restricted to eutrophic or hypertrophic systems, but also occur in nutrient poorer (oligo-mesotrophic) lakes and reservoirs and can even be promoted by oligotrophication [119-123]. It is essential to realise that cyanobacteria are not a homogenous group when trying to understand $\mathrm{CHAB}$ dynamics and bloom response to mitigating or promoting factors and management strategies. Therefore, the first step of any bloom management should be a careful analysis of the in-situ situation, including the identification of the predominant bloom species. cHABs forming cyanobacteria can be clustered into two groups based on their nutrient preferences and their likelihood to form blooms: Cyanobacteria genera typically forming surface blooms in N-limited systems are $\mathrm{N}_{2}$-fixing (dinitrogen) taxa (Dolichospermum, Cylindrospermopsis, Aphanizomenon, Lyngbya and Nodularia) as they can compensate for $\mathrm{N}$ limitation by using atmospheric $\mathrm{N}_{2}$. Planktothrix blooms are typically found in mesotrophic lakes [120], where they produce deep chlorophyll maxima. Genera typically occurring in eutrophic, P- and N-rich systems are Microcystis and Cylindrospermopsis [124,125].

Several studies have summarised cHAB monitoring and management strategies [126-129]. The suitability and success of the respective strategy might vary and should be considered carefully on a case-by-case basis $[116,125]$. Nutrient control and reduction is still considered to be the most efficient management tool. Here again, a detailed analysis of the in-situ situation should be the first step. This includes a characterisation of the reservoir by its trophic level index and the identification of nutrient sources and their pathways. Nutrients can enter the system 
via point sources like natural and artificial tributaries, water transitions, by pumping water from another system into the reservoir (especially in the case of pump storage hydropower reservoirs) or can originate from diffuse sources from the catchment area. The German environment agency (Umweltbundesamt (UBA)) developed a decision support system for reservoir management (https: / / toxic-cyanobacteria.com/ (accessed on 14 April 2021)), which summarises background information and questionnaires linked with cyanobacterial blooms and toxins. This tool might deliver an overview of the situation and help to develop a water safety plan. Besides the described direct control of nutrient input, a reduction might also be achieved via sediment dredging or flushing and binding or precipitation of nutrients via flocculating agents. These invasive strategies should however be considered carefully, as they often come with negative ecological impact or high economic costs $[125,130]$. Finally, physical factors are often manipulated to mitigate cHABs. Physical measures include disintegration of vertical stratification and increased flushing rates in reservoirs [128]. Vertical mixing devices to break down stratification have been successfully applied in small lakes and reservoirs [125]. The efficacy and applicability of these physical manipulations primarily depend on the size and purpose of the reservoir, the predominant bloom species and should be applied in parallel with nutrient control [128].

\subsection{Greenhouse Gas Emissions}

Dammed systems release substantial amounts of greenhouse gases (GHG) that contribute considerably to the global GHG budget [131-135]. Especially $\mathrm{CH}_{4}$ is of major concern with reservoirs emitting 8.9-22.2 t/yr of $\mathrm{CH}_{4}$ globally [136]. GHG emissions depend on the location and construction of the reservoir and on its management. The conditions in the catchment determine inflow of nutrients and the amount of organic carbon that is eventually stored in the sediments. The meteorological conditions affect the strength of stratification, the duration of the season, the intensity of vertical mixing in the water column and of the gas exchange at the water surface. The morphometry of the reservoir together with meteorological conditions and the amount of organic material in the sediments determines, whether anoxic conditions develop in the deep water which support accumulation of $\mathrm{CH}_{4}$ and $\mathrm{CO}_{2}$ and eventually lead to GHG emission during fall overturn, or to emissions downstream of the dam if the outlet of the reservoir is located in the anoxic layer.

Reservoir management may alter the efficiency of different GHG emission pathways. The vertical position and the temporal sequence of water inflow and withdrawal can have substantial effects on GHG emissions. Continuous deep-water withdrawal may remove GHG and nutrients released from the sediments to downstream river reach. Nutrient removal may result in reduced within-system production, thus yields in a smaller accumulation of organic material in the sediments and consequently a reduced GHG production. The removal of cold deep-water reduces stratification, thus supports vertical mixing of e.g., oxygen. In contrast, withdrawal near the water surface may directly remove algae and cyanobacteria from the system and thus reduces organic material, but favours the development of a strong stratification with reduced mixing. The latter increases the risk of anoxia and GHG accumulation in the deep water. In case water removal is not continuous but operated as a single major drawdown of the reservoir, the pressure release on the $\mathrm{CH}_{4}$ saturated pore-water causes the formation of $\mathrm{CH}_{4}$ bubbles and thus a substantial increase in $\mathrm{CH}_{4}$ emissions via ebullition [137-141]. If this drawdown is conducted after the stratification period, it may additionally cause substantial downstream GHG emissions if $\mathrm{CO}_{2}$ and $\mathrm{CH}_{4}$ had been accumulated in anoxic waters. In case small drawdowns are conducted at regular time intervals the overall $\mathrm{CH}_{4}$ emissions via ebullition may be smaller than for an operation with no withdrawal followed by one single large drawdown per year. Inflow of water at the largest depth may be advantageous for reducing GHG emissions. Since the inflowing water is typically warmer and enriched in oxygen compared to the deep water, stratification is reduced which supports the vertical transport by mixing, and the deep water is oxygenated which enhances oxidation of $\mathrm{CH}_{4}$ at the sediment water interface and 
prevents accumulation of $\mathrm{CH}_{4}$ that could be released during fall overturn. Pump-storage operation with turbination and inflow of water in the deep water may be particularly advantageous with respect to GHG emissions, as the ebullition fluxes during regular small drawdowns lead to comparatively small $\mathrm{CH}_{4}$ emissions and the inflow of water in the deep water supports its oxygenation and the oxidation of $\mathrm{CH}_{4}$ at the sediment-water interface, thus preventing accumulation of $\mathrm{CH}_{4}$ [142]. Another effect of regular water fluctuations (e.g., in a pump-storage system) is the periodic drying and wetting of near shore sediments which may reduce $\mathrm{CH}_{4}$ fluxes from these sediments.

\subsection{Societal Implications}

The social surrounding is linked in a myriad of ways to most processes within and around the reservoir, connected e.g., to the land use, the social fabric and the governance, from the first planning stages to the implemented infrastructure. Social impacts of reservoirs therefore occur in a complex setting of time, space and value spheres [8-10,19,143-148]. The land use in the upstream catchment area influences amongst others erosion processes, the resulting sediment yield and the amount of sediments which reach rivers and reservoirs (see Section 3.1), nutrient input, e.g., from agricultural uses [149] or sewage treatment plants, but also hydrological aspects $[22,150,151]$. Downstream riparian may also have demands regarding water quantity and quality (sediments such as the general suspended load, nutrients). There are many ecological concerns, as some reservoirs, due to their history, do not meet minimal discharge requirements or incorporate pass-through installations for aquatic organisms, thus failing to comply with the e.g., EU water framework directive [152-155]. People living nearby may benefit from the reservoirs in various ways: water storage ensures drinking and irrigation water supply, there are recreational opportunities as well as affiliated economic advantages like employment in hydropower enterprises or tourism, influencing the perception [156]. But differing interests of stakeholders in the use of the reservoir and resource can lead to conflicts, e.g., in connection to agricultural uses and nature protection versus recreation and other economic uses, especially concerning energy production [157-162].

Renewable energy production is one major focus of concern and is naturally fluctuating with the availability of solar radiation, wind speed and discharge within river systems to meet the actual present need for electrical power. With hydropower use of the reservoir (especially pump storage) it is possible to no longer be dependent on the availability of solar radiation, wind and discharge; now it is possible to follow a variable demand structure. A direct consequence of active reservoir management to produce hydropower energy on demand are resulting water level changes that may provoke conflict, especially if there is recreational and, or an environment with nature conservation status present [163]. As hydropower production will lead to water level changes within the reservoir but also downstream, recreational facilities on the shore, nature protection areas or downstream riparian floodplains will be subject to drastic water level changes thereby impede full flexibility $[164,165]$ and the management needs to address all hydrological requirements in the catchment area. Pump storage power plants are systems, where not only water from the catchment is collected within the reservoir, but also water from different origins can be pumped into the reservoir. However, if pumping introduces water from a different catchment into the reservoir it may lead to challenges e.g., in respect to nutrient content [165] (see Section 3.3). If the reservoir is part of a profitable touristic system, these interests may play a major role in the management of the reservoir. Frequent water level fluctuations, water quality issues, an active sediment management (e.g., by dredging or flushing) and health risks (e.g., due to cHABs) and economic impacts will be topics of considerable concern $[149,166]$. Additionally, invasive species, e.g., aquatic birds, may also be an issue in stagnant water bodies in respect to the former free flowing conditions [167].

The regulations on nature protected areas or even national parks in proximity govern possible interference in the (hydrological) system and therefore, if present, will be influencing management profoundly ( $\$ 23$ and 24 in the German Federal Nature Conservation Act). There may be conflicts regarding accessibility of the reservoir if it is restricted due to 
hydro-energy installation or nature protection areas. In case of drinking water reservoirs, regulations are in place that ensure water quality and govern water use, restrict access and regulate possible emitters of pollutants within the catchment $[168,169]$. Then, usually drinking water supply will be the predominant purpose and other uses, e.g., flood protection or hydro energy production, will only be authorised if they do not impair this vital function. If the implementation of drinking water protection area leads to economic losses for other usages (e.g., agriculture, forestry), compensation is required by German law ( 52 Abs. 5 WHG, § 96 Abs. 2 WHG of the German water law). Furthermore, water supply (drinking and irrigation water) may be an increasing issue considering demographic changes and changing precipitation patterns and resulting dry seasons, especially in the future due to climate change [170].

Many reservoirs have to fulfil the additional function of flood protection and are part of a decentralised flood control system. When advisable, a water level drawdown is required prior to an imminent flood event to provide additional protection volume [171] Hydropower companies will not be in favour of turbining large amounts of water during periods of low revenue. However, in worst case the water level has to be lowered in an even shorter period, leading to the opening of the gates and the release of water to the downstream river stretch, without using the released water for the generation of electricity, which may be a point of conflict. Downstream riparian will usually benefit from a more constant water flow through the installed dam that will attenuate extreme high/low water runoff events over the year. The attenuated water flow can also be a critical point in the natural environment which may be dependent on extreme runoff events [155]. An active communicating management was perceived quite positively by most of the stakeholders, even though nature protection seems to be, out of the sheer size and influence of water storing infrastructure, one of the harder to solve challenges in the researched case studies [166]. Overall, there are manifold interests present related to reservoirs, which are-in an ideal case-all incorporated in a comprehensive reservoir management or an integrated water resources management to fulfil the diverse demands towards reservoirs [172]. The following section will summarise the findings and introduce the tool developed by the authors.

\section{Findings of the CHARM Project and Setup of the Tool}

The management of reservoirs affects a multitude of interests and aspects in and around the actual water body depending on the main function of the system. Most reservoirs serve multiple purposes and are therefore prone to conflicts of interest between these uses. During the CHARM project, extensive research was carried out on five aspects of reservoir management, discussed in the previous sections, to gain deeper insight into dominating processes and especially the interlinkages between these aspects. Discussions took place within the consortium in order to consolidate the knowledge and to identify the challenges of reservoir management through the analysis of project-related results (laboratory, field, numerical, empirical stakeholder analysis) and pivotal papers https: //milan-daus.github.io/Literature-on-Water-Reservoir-Management. Accordingly, as an attempt to support the achievement of the Sustainable Development Goals (SDG) of the United Nations objectives in the water sector [173], more precisely in the storage of this fundamental resource, a conceptual tool was developed that provides an overview of the interdependence and interactions between different factors of reservoir management. The interactions of the environmental, technical and social spheres are quite complicated, therefore the CHARM project aimed at providing a holistic approach see Figure 5. The management of water resources needs to incorporate environmental, technical and societal demands to guarantee a sustainable use of the resource. This loop model displays the interactions and interconnections to satisfy a sustainable management. 


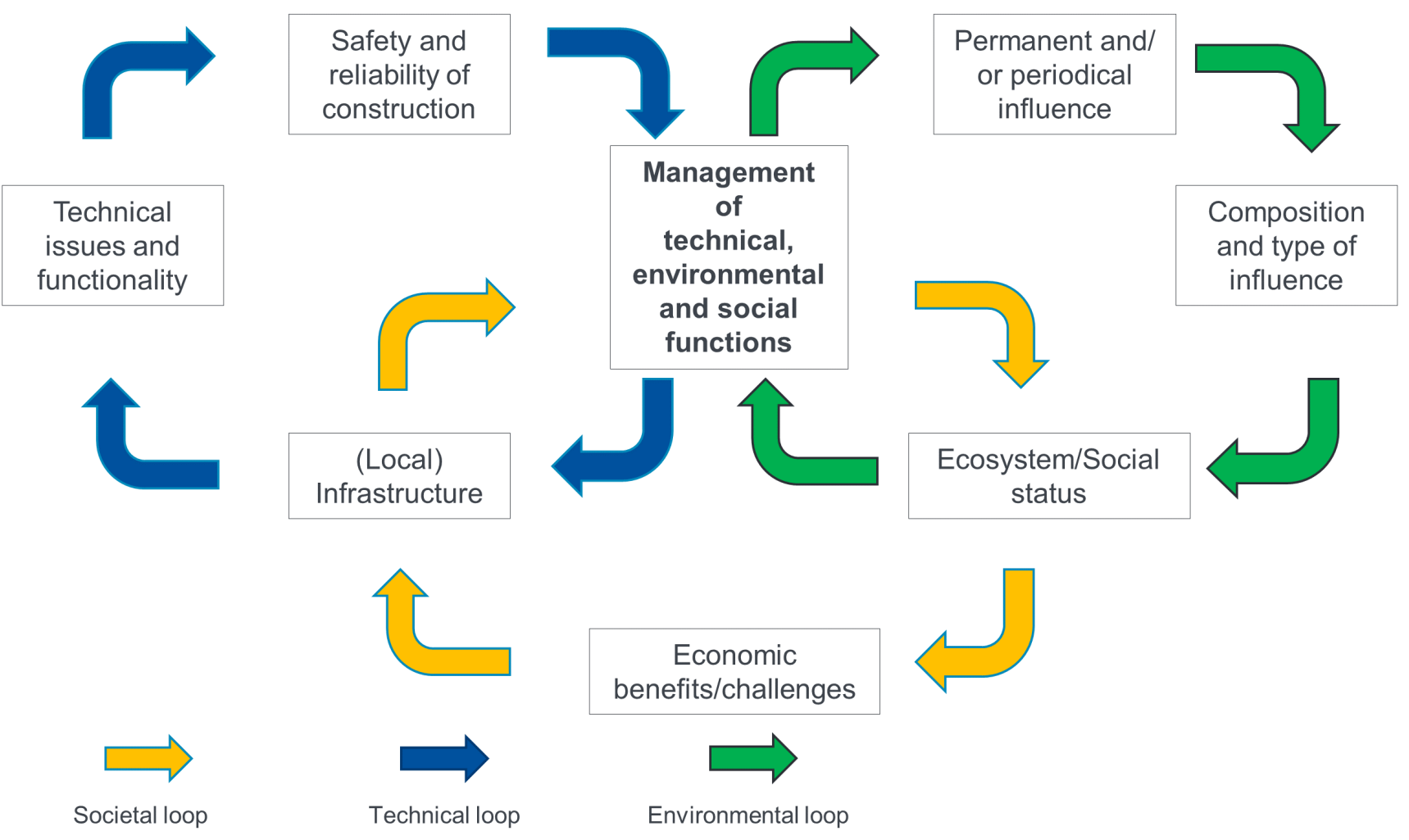

Figure 5. Synopsis of the implication spheres as an input parameter for the tool.

In this approach the user of the tool gets a comprehensive overview through information, stored within the individual sheets in the file, accessible via mouse click on active fields. These interactions and implications are embraced by an automated redirection to corresponding points and information by clicking on active elements in the tool see Figure 6. For usability and an easier access to the functions of the tool, the structure was set up in Microsoft Excel. A descriptive matrix, as one centre for information, based on the idea of cross-impact-matrices [36] can identify certain interrelations of typical reservoir management issues (see Figure 7) and was put together via delphi questioning of the research consortium. The impacts of different environmental, technical and social implications are cross analysed with all other columns or rows to provide information about impacts of factors and their relation and direction of effect in 49 columns and rows. The labelling of the matrix cross-impact content therefore stands for explicit and directed impacts. To give an example of the content in the matrix: One box can set the cross impact in implication A on the $y$ axis (columns) impacts implication B on the $x$ axis (rows), vice versa, is the same, leads to more/less y, precluding each other and so on. The intended cross impact matrices would possibly need to be reconfigured by the individual user to fit other case studies. 
The research interest on reservoirs is manifold, yet a comprehensive and integrative information tool is not available. Therefore, the tool presented here is based on the results from the CHARM (CHAllenges of Reservoir Management) project as well as the condensed outcome of relevant literature to aid and enhance knowledge in water reservoir management. The project focused on five different topics of interest in relation to existing water reservoirs, namely: sedimentation of reservoirs, biostabilisation of fine sediments, toxic cyanobacteria(l) (blooms), greenhouse gas emissions from reservoirs and social contestation respectively approval. These five research foci contributed to the topics and setup of this tool. The project worked on case studies in Germany, namely the Schwarzenbach dam and the Kleine Kinzig reservoir in the state of Baden-Wuerttemberg and the Lakes of the Franconian Lake District in the state of Bavaria.
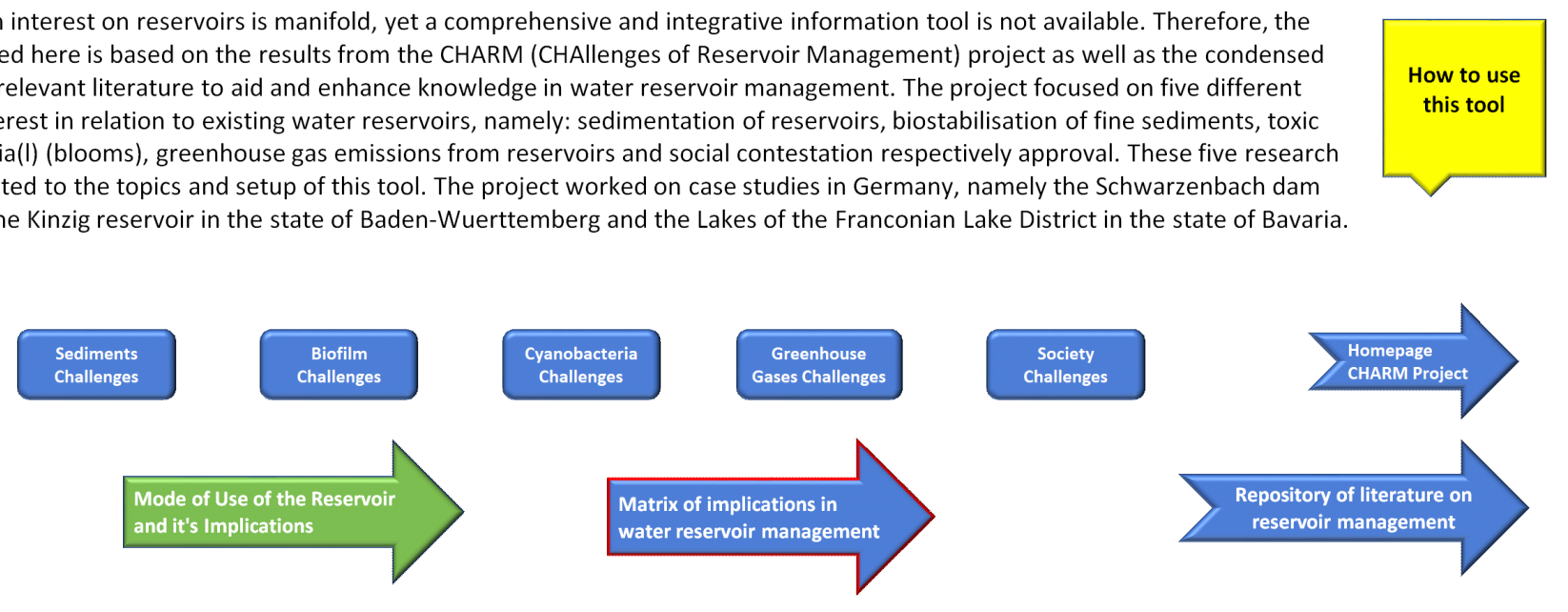

Figure 6. Landing page of the tool; download at: https://github.com/milan-daus/Literature-on-Water-ReservoirManagement.

\begin{tabular}{|c|c|c|c|c|c|c|c|}
\hline $\begin{array}{l}\text { Cross-Impact } \\
\text { Matrix }\end{array}$ & 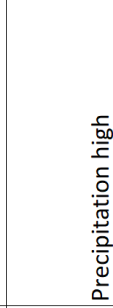 & $\begin{array}{l}\frac{3}{0} \\
\frac{0}{0} \\
\frac{0}{0} \\
\frac{0}{0} \\
\frac{0}{\overline{0}} \\
\frac{0}{0}\end{array}$ & 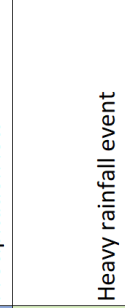 & 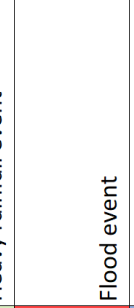 & 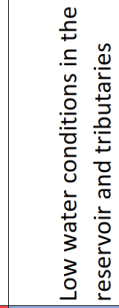 & 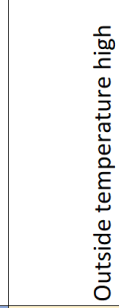 & 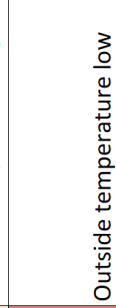 \\
\hline Precipitation high & & $x \neq y$ & $x^{\wedge} ! y$ & $x \rightarrow y$ & $x \neq y$ & $x->>! y$ & $x->! y$ \\
\hline Precipitation low & $x \neq y$ & & $0 x \neq y$ & $x \neq y$ & $x \rightarrow y$ & - & - \\
\hline Heavy rainfall event & $x=y / x \rightarrow y$ & $x \neq y$ & & $0 x->! y$ & $x \neq y$ & - & - \\
\hline Flood event & - & - & - & & $x \neq y$ & - & 1 \\
\hline $\begin{array}{l}\text { Low water conditions in the } \\
\text { reservoir and tributaries }\end{array}$ & $5^{-}$ & 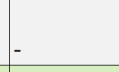 & - & $x \neq y$ & & - - & \\
\hline Outside temperature high & $x^{\wedge} ! y$ & $x^{\wedge} ! y$ & $x^{\wedge} ! y$ & $x^{\wedge} ! y$ & $x^{\wedge} ! y$ & & $x \neq y$ \\
\hline Outside temperature low & $x^{\wedge} ! y$ & $x^{\wedge} ! y$ & - & $x^{\wedge} ! y$ & $x^{\wedge} ! y$ & $x \neq y$ & \\
\hline
\end{tabular}

(a) Matrix impression

\begin{tabular}{|l|l|l|}
\hline Abbreviation & Colourcode & Meaning \\
\hline- & No connection or interaction \\
\hline$X=Y$ & $X$ and $Y$ are the same \\
\hline$X \neq Y$ & $X$ and $Y$ preclude each other \\
\hline$X->Y$ & $X$ leads to $Y$ \\
\hline$X->! y$ & $X$ may lead to $Y$ \\
\hline$X^{\wedge} Y$ & $X$ affects $Y$ \\
\hline$X^{\wedge} ! Y$ & $X$ may affect $Y$ \\
\hline$X-><Y$ & $X$ leads to more $Y$ \\
\hline$X->>Y$ & X leads to less $Y$ \\
\hline$X->>! Y$ & X may lead to less $Y$ \\
\hline$X->Z->Y$ & $\begin{array}{l}X \text { leads via an intermediate } \\
\text { step to } Y\end{array}$ \\
\hline$X->! Z->Y$ & $\begin{array}{l}X \text { leads via an uncertain } \\
\text { intermediate step to } Y\end{array}$ \\
\hline$X->Z-><Y$ & $\begin{array}{l}X \text { leads via an intermediate } \\
\text { step to more } Y\end{array}$ \\
\hline$X->Z->>Y$ & $\begin{array}{l}X \text { leads via an intermediate } \\
\text { step to less } Y\end{array}$ \\
\hline$X->Z Z->Y$ & $\begin{array}{l}X \text { leads via several } \\
\text { intermediate steps to } Y\end{array}$ \\
\hline$X->Z Z-><Y$ & $\begin{array}{l}X \text { leads via several } \\
\text { intermediate steps to more }\end{array}$ \\
\hline$X->Z Z->>Y$ & $\begin{array}{l}X \text { leads via several } \\
\text { intermediate steps to less } Y\end{array}$ \\
\hline $\begin{array}{l}\text { Combinations } \\
\text { of the above }\end{array}$ & $\begin{array}{l}\text { Individual combination of } \\
\text { the above }\end{array}$ \\
\hline $\begin{array}{l}\text { P/More than } \\
\text { one }\end{array}$ & $\begin{array}{l}\text { User has to define own } \\
\text { weighting }\end{array}$ \\
\hline
\end{tabular}

(b) Legend for matrix

Figure 7. Extract of the matrix with corresponding legend.

The topics include e.g., precipitation, water level fluctuations, nutrients in the water body, economic/environmental conflict, social implications etc., substitute for the five previously discussed challenges of reservoir management, namely: sedimentation of reservoirs, biostabilisation of fine sediments, toxic cyanobacteria(l) (blooms), greenhouse gas emissions from reservoirs (mainly $\mathrm{CH}_{4}$ and $\mathrm{CO}_{2}$ ) and social conflict(s). The research was carried out in a case study perspective from southern Germany for empirical studies at SBT $\left(48^{\circ} 39^{\prime} 21.5^{\prime \prime}\right.$ N $8^{\circ} 19^{\prime} 36.4^{\prime \prime}$ E), Large Lake Brombach, Small Lake Brombach, Lake Igelsbach, Lake Altmühl and Lake Roth all from the reservoir system FLD $\left(49^{\circ} 13^{\prime} 16.7^{\prime \prime} \mathrm{N}, 10^{\circ} 92^{\prime} 67.3^{\prime \prime} \mathrm{E}\right.$ ) (see Figure 2) and incorporated research results and basic, respectively specific literature on the topic https:/ / github.com/milan-daus/Literature-on-Water-Reservoir-Management to promote solutions for a holistic water resources management. To get an impression of the landing page of the tool, see Figure 6. This landing page enables the user to get to the 
relevant individual information desired and covered by the tool by clicking on activated elements and that way be guided through the content.

With all benefits, there will of course also be limitations in the provided information, since within the matrix mainly the before mentioned case studies were implemented. Hence, implications only found in literature may be underrepresented. This holds especially true, if the societal and political sphere is considered. Since the results are strongly rooted in German federal/ state and EU law, the information and implications presented here may have less significance in different geographical and political context. The topics researched in the CHARM project were being selected critically by the disciplines involved in the project. Nevertheless, there are many other topics the project could not cover and therefore the tool cannot either. The use of the tool is possible in professional and semi-professional audiences, being interested professionally or personally in reservoir management topics. If people use the tool, there are chances to further improve it by integrating more implications of other case studies. The application of this tool for experts and laymen and the evaluation of the presented interdependence for other multi-purpose reservoirs can be seen as encouraging examples to create transparency, to improve the management and support decision making of water resources management in established storage systems, where an active management is of central importance to water-food-energy nexus in pursuit of meeting the SDG.

\section{Conclusions and Outlook}

On a global scale, the need for storing water for energy, irrigation and drinking water increases, resulting in an acceleration of the construction of dams and reservoirs in the last century to a number of over 58,000 large dams worldwide [3]. These dams and reservoirs have very different impacts amongst others on a local, regional, but also global scale, depending on their location in the sense of catchment specifics, type of infrastructure, size and quantity of water stored, the main function of the reservoir, social and economical interaction in adjacent areas (or possibly even resettlement of people), political and juridical standards (also in the downstream river stretch) and general discourses around dams, respectively a specific case. Different reservoir projects created a lot of attention around the world, especially if there were different international interests present that regard governance of water resources [146,147,174,175].

Even though, the boom of dam building in Germany may be in the past, the positive and negative impacts are outlasting time and are (still) visible today $[4,176]$. The project CHARM aimed at finding answers to (future) challenges in reservoir management for reservoirs in a European context [7]. This was done by researching different case studies from southern Germany. A descriptive tool was developed to create a holistic overview and contribute to sustainable water management in Germany. This means all results are linked to those places, but could be generalised to match a meta level of management implications, also on an international scale. As mentioned above, the transferability of the implications is not always trivial, or even possible. Still this will emphasise the user of the tool to look beyond the mere case studies and get a comprehensive overview, possibly enhance the knowledge by transferring it to other case studies. As the tool is also compromised by a fair amount of best practice examples from literature, the authors could verify, that there is no comparable tool available so far to be used by the interested public, same as experts in the field. As dissemination and information of the public is compelling to such a tool, it is therefore vital to provide a public domain to access the data. It is eligible for the future to develop drop down options for the users, to simplify the process of filling out the matrix. Furthermore, a thematic enhancement of the focus towards ecological and environmental issues is desirable. These steps would take the information on the next level to guide reservoir management and contribute to a sustainable water resources management in order to foster the Sustainable Development Goals (SDG), developed by the United Nations, and gain knowledge about (future) challenges in water resources research. 
Author Contributions: Conceptualisation, M.D., K.K. (Katharina Koberger); methodology, M.D., K.K. (Katharina Koberger), K.K. (Kaan Koca) and F.B.; data curation, M.D., K.K. (Katharina Koberger), K.K. (Kaan Koca) and F.B.; writing-Original draft preparation, M.D., K.K. (Katharina Koberger), K.K. (Kaan Koca), F.B., J.E.F., B.W., D.D., S.U.G., R.G., S.H., H.H., D.M.-C., F.P. and S.W.; writingReview and editing, M.D., F.B., K.K. (Kaan Koca), S.H., F.P., S.U.G. and R.G.; visualisation, M.D., K.K. (Katharina Koberger), K.K. (Kaan Koca), R.G. and F.B.; supervision, M.D., K.K. (Katharina Koberger) and R.G. All authors have read and agreed to the published version of the manuscript.

Funding: This study was carried out in the interdisciplinary research project CHARM-CHAllenges of Reservoir Management-Meeting Environmental and Social Requirements. The project is financially supported by the Wassernetzwerk Baden-Württemberg (Water Network of the federal state of BadenWuerttemberg), which is funded by the Ministerium für Wissenschaft, Forschung und Kunst BadenWürttemberg (Ministry of Science, Research and the Arts of the federal state of Baden-Wuerttemberg), grant number: Az. 33-7533.-25-11.

Data Availability Statement: The excel tool that presents key aspects of management-related issues and their interrelations can be accessed at: https:/ / github.com/milan-daus/Literature-on-WaterReservoir-Management, while the relevant literature is available at: https://milan-daus.github. io/Literature-on-Water-Reservoir-Management/. The literature list is also accessible under: https: //github.com/milan-daus/Literature-on-Water-Reservoir-Management. All Github links in the paper were last accessed on the 15 April 2021.

Acknowledgments: The authors would like to thank all (former) project members of the CHARM project to make this publication possible with great effort. Namely Markus Noack, Michelle Dietz, Kevin Rütschlin, Ole Lessmann, Julie Hope and Thomas Haas. The authors would also like to thank Mathilde Erfurt for technical support. Furthermore the authors would like to thank four anonymous reviewers for their valuable input and important advises on the improvement of an early draft of this manuscript. The article processing charge was funded by the Baden-Wuerttemberg Ministry of Science, Research and Art and the University of Freiburg in the funding programme Open Access Publishing.

Conflicts of Interest: The authors have no conflict of interest to declare that are relevant to the content of this article.

\section{References}

1. Glaser, R. Global Change: Das neue Gesicht der Erde; Primus Verlag: Darmstadt, Germany, 2014.

2. Peteuil, C.; Jodeau, M.; De Linares, M.; Valette, E.; Alliau, D.; Wirz, C.; Fretaud, T.; Antoine, G.; Secher, M. Toward an operational approach for the characterization and modelling of fine sediments dynamics in reservoirs. E3S Web Conf. 2018, 40, 03028. [CrossRef]

3. Mulligan, M.; van Soesbergen, A.; Sáenz, L. GOODD, a global dataset of more than 38,000 georeferenced dams. Sci. Data 2020, 7, 31. [CrossRef]

4. Blackbourn, D. Die Eroberung der Natur: Eine Geschichte der Deutschen Landschaft; DVA: München, Germany, 2007.

5. Deutsches Talsperren Kommitee (Ed.) Talsperren in Deutschland; Springer Vieweg: Wiesbaden, Germany, 2013. [CrossRef]

6. Döll, P.; Fiedler, K.; Zhang, J. Global-scale analysis of river flow alterations due to water withdrawals and reservoirs. Hydrol. Earth Syst. Sci. 2009, 13, 2413-2432. [CrossRef]

7. Beckers, F.; Haun, S.; Gerbersdorf, S.U.; Noack, M.; Dietrich, D.R.; Martin-Creuzburg, D.; Peeters, F.; Hofmann, H.; Glaser, R.; Wieprecht, S. CHARM-Challenges of Reservoir Management : Meeting Environmental and Social Requirements. Hydrolink 2018, 3, 80-82.

8. Kirchherr, J.; Pohlner, H.; Charles, K.J. Cleaning up the big muddy: A meta-synthesis of the research on the social impact of dams. Environ. Impact Assess. Rev. 2016, 60, 115-125. [CrossRef]

9. Kirchherr, J.; Charles, K.J. The social impacts of dams: A new framework for scholarly analysis. Environ. Impact Assess. Rev. 2016, 60, 99-114. [CrossRef]

10. Zarfl, C.; Lumsdon, A.E.; Berlekamp, J.; Tydecks, L.; Tockner, K. A global boom in hydropower dam construction. Aquat. Sci. 2015, 77, 161-170. [CrossRef]

11. Denaro, S.; Anghileri, D.; Giuliani, M.; Castelletti, A. Informing the operations of water reservoirs over multiple temporal scales by direct use of hydro-meteorological data. Adv. Water Resour. 2017, 103, 51-63. [CrossRef]

12. Feng, M.; Shen, Z. Assessment of the Impacts of Land Use Change on Non-Point Source Loading under Future Climate Scenarios Using the SWAT Model. Water 2021, 13, 874. [CrossRef]

13. Pelikán, P.; Hubačíková, V.; Kaletová, T.; Fuska, J. Comparative Assessment of Different Modelling Schemes and Their Applicability to Inland Small Reservoirs: A Central Europe Case Study. Sustainability 2020, 12, 10692. [CrossRef] 
14. Rafique, A.; Burian, S.; Hassan, D.; Bano, R. Analysis of Operational Changes of Tarbela Reservoir to Improve the Water Supply, Hydropower Generation, and Flood Control Objectives. Sustainability 2020, 12, 7822. [CrossRef]

15. Reisenbüchler, M.; Bui, M.D.; Rutschmann, P. Reservoir Sediment Management Using Artificial Neural Networks: A Case Study of the Lower Section of the Alpine Saalach River. Water 2021, 13, 818. [CrossRef]

16. Panagopoulos, Y.; Dimitriou, E. A Large-Scale Nature-Based Solution in Agriculture for Sustainable Water Management: The Lake Karla Case. Sustainability 2020, 12, 6761. [CrossRef]

17. Gunkel, G.; Selge, F.; Keitel, J.; Lima, D.; Calado, S.; Sobral, M.; Rodriguez, M.; Matta, E.; Hinkelmann, R.; Casper, P.; et al. Water management and aquatic ecosystem services of a tropical reservoir (Itaparica, São Francisco, Brazil). Reg. Environ. Chang. 2018, 18, 1913-1925. [CrossRef]

18. Acciarri, M.F.; Checola, S.; Galli, P.; Magatti, G.; Stefani, S. Water Resource Management and Sustainability: A Case Study in Faafu Atoll in the Republic of Maldives. Sustainability 2021, 13, 3484. [CrossRef]

19. World Commission on Dams. Dams and Development: A New Framework for Decision-Making: The Report of the World Commission on Dams; Roouthledge: London, UK, 2000. [CrossRef]

20. Allan, J.D.; Smith, S.D.P.; McIntyre, P.B.; Joseph, C.A.; Dickinson, C.E.; Marino, A.L.; Biel, R.G.; Olson, J.C.; Doran, P.J.; Rutherford, E.S.; et al. Using cultural ecosystem services to inform restoration priorities in the Laurentian Great Lakes. Front. Ecol. Environ. 2015, 13, 418-424. [CrossRef]

21. Schulz, C. Governance-related values as dimensions of good water governance. Wiley Interdiscip. Rev. Water 2019, 6, e1322. [CrossRef]

22. Pahl-Wostl, C. Water Governance in the Face of Global Change: From Understanding to Transformation, 1st ed.; Water GovernanceConcepts, Methods, and Practice; Springer: Cham, Switzerland, 2015. [CrossRef]

23. Schulz, C.; Adams, W.M. In search of the good dam: Contemporary views on dam planning in Latin America. Sustain. Sci. 2020 [CrossRef]

24. Siegmund-Schultze, M.; Köppel, J.; Sobral, M.d.C. Balancing ecosystem services and societal demands in a highly managed watershed: Setup and progress of a comprehensive research project. Rev. Bras. Cienc. Ambient. (Online) 2015, 36, 3-18. [CrossRef]

25. Souza da Silva, G.N.; de Moraes, M.M.G.A. Economic water management decisions: Trade-offs between conflicting objectives in the sub-middle region of the São Francisco watershed. Reg. Environ. Chang. 2018, 18, 1957-1967. [CrossRef]

26. Flyvbjerg, B. The Oxford Handbook of Megaproject Management, 1st ed.; Oxford Handbooks; Oxford University Press: Oxford, $\mathrm{UK}, 2017$.

27. Wu, X.; Li, S.; Cheng, C.; Miao, S.; Ying, Q. Simulation-Optimization Model to Derive Operation Rules of Multiple Cascaded Reservoirs for Nash Equilibrium. J. Water Resour. Plan. Manag. 2019, 145, 04019013. [CrossRef]

28. Geressu, R.T.; Harou, J.J. Reservoir system expansion scheduling under conflicting interests. Environ. Model. Softw. 2019, 118, 201-210. [CrossRef]

29. Weber, M.; Rinke, K.; Hipsey, M.R.; Boehrer, B. Optimizing withdrawal from drinking water reservoirs to reduce downstream temperature pollution and reservoir hypoxia. J. Environ. Manag. 2017, 197, 96-105. [CrossRef] [PubMed]

30. Guariso, G.; Sangiorgio, M. Performance of Implicit Stochastic Approaches to the Synthesis of Multireservoir Operating Rules. J. Water Resour. Plan. Manag. 2020, 146, 04020034. [CrossRef]

31. Soncini-Sessa, R. Integrated and participatory water resources management: Theory. In Developments in Integrated Environmental Assessment; Elsevier: Amsterdam, NY, USA, 2007; Volume 1A.

32. Labadie, J.W. Optimal Operation of Multireservoir Systems: State-of-the-Art Review. J. Water Resour. Plan. Manag. 2004, 130, 93-111. [CrossRef]

33. Castelletti, A.; Giuliani, M.; Soncini-Sessa, R. Water Resources Planning and Management in a Changing Climate and Society. In Innovations in Land, Water and Energy for Vietnam's Sustainable Development; Anderle, M., Ed.; UNIPA Springer Series; Springer International Publishing and Springer: Cham, Switzerland, 2021.

34. Green, K.; Armstrong, J.S.; Graefe, A. Methods to Elicit Forecasts from Groups: Delphi and Prediction Markets Compared. Foresight Int. J. Appl. Forecast. 2007, 8, 17-20.

35. Mauksch, S.; von der Gracht, H.A.; Gordon, T.J. Who is an expert for foresight? A review of identification methods. Technol. Forecast. Soc. Chang. 2020, 154, 119982. [CrossRef]

36. Weimer-Jehle, W. Cross-impact balances: A system-theoretical approach to cross-impact analysis. Technol. Forecast. Soc. Chang. 2006, 73, 334-361. [CrossRef]

37. International Commission on Large Dams. World Register of Dams: General Synthesis; 2019. Available online: https://www.icoldcigb.org/GB/world_register/general_synthesis.asp (accessed on 14 April 2021).

38. Nilsson, C.; Reidy, C.A.; Dynesius, M.; Revenga, C. Fragmentation and Flow Regulation of the World's Large River Systems. Science 2005, 308, 405-408. [CrossRef] [PubMed]

39. Syvitski, J.P.M.; Vörösmarty, C.J.; Kettner, A.J.; Green, P. Impact of Humans on the Flux of Terrestrial Sediment to the Global Coastal Ocean. Science 2005, 308, 376-380. [CrossRef]

40. Mouris, K.; Beckers, F.; Haun, S. Three-dimensional numerical modeling of hydraulics and morphodynamics of the Schwarzenbach reservoir. E3S Web Conf. 2018, 40, 03005. [CrossRef]

41. Morris, G.L.; Fan, J. Reservoir Sedimentation Handbook: Design and Management of Dams, Reservoirs, and Watersheds for Sustainable Use; McGraw Hill: New York, NY, USA, 1998. 
42. Haun, S.; Kjærås, H.; Løvfall, S.; Olsen, N.R.B. Three-dimensional measurements and numerical modelling of suspended sediments in a hydropower reservoir. J. Hydrol. 2013, 479, 180-188. [CrossRef]

43. Black, K.S.; Tolhurst, T.J.; Paterson, D.M.; Hagerthey, S.E. Working with Natural Cohesive Sediments. J. Hydraul. Eng. 2002, 128, 2-8. [CrossRef]

44. Gerbersdorf, S.U.; Jancke, T.; Westrich, B.; Paterson, D.M. Microbial stabilization of riverine sediments by extracellular polymeric substances. Geobiology 2008, 6, 57-69. [CrossRef]

45. Noack, M.; Gerbersdorf, S.; Hillebrand, G.; Wieprecht, S. Combining Field and Laboratory Measurements to Determine the Erosion Risk of Cohesive Sediments Best. Water 2015, 7, 5061-5077. [CrossRef]

46. Schäfer Rodrigues Silva, A.; Noack, M.; Schlabing, D.; Wieprecht, S. A data-driven fuzzy approach to simulate the critical shear stress of mixed cohesive/non-cohesive sediments. J. Soils Sediments 2018, 18, 3070-3081. [CrossRef]

47. Beckers, F.; Inskeep, C.; Haun, S.; Schmid, G.; Wieprecht, S.; Noack, M. High spatio-temporal resolution measurements of cohesive sediment erosion. Earth Surf. Process. Landforms 2020, 4, 43. [CrossRef]

48. Haun, S.; Olsen, N.R.B. Three-dimensional numerical modelling of reservoir flushing in a prototype scale. Int. J. River Basin Manag. 2012, 10, 341-349. [CrossRef]

49. Beckers, F.; Haun, S.; Noack, M. Experimental investigation of reservoir sediments. E3S Web Conf. 2018, 40, 03030. [CrossRef]

50. Pohlert, T.; Hillebrand, G.; Breitung, V. Trends of persistent organic pollutants in the suspended matter of the River Rhine. Hydrol. Process. 2011, 25, 3803-3817. [CrossRef]

51. Majerová, L.; Bábek, O.; Navrátil, T.; Nováková, T.; Štojdl, J.; Elznicová, J.; Hron, K.; Matys Grygar, T. Dam reservoirs as an efficient trap for historical pollution: The passage of $\mathrm{Hg}$ and $\mathrm{Pb}$ through the Ohře River, Czech Republic. Environ. Earth Sci. 2018, 77, 2596. [CrossRef]

52. Graf, W.L. Downstream hydrologic and geomorphic effects of large dams on American rivers. Geomorphology 2006, 79, 336-360. [CrossRef]

53. Magilligan, F.J.; Nislow, K.H. Changes in hydrologic regime by dams. Geomorphology 2005, 71, 61-78. [CrossRef]

54. Wu, H.; Chen, J.; Xu, J.; Zeng, G.; Sang, L.; Liu, Q.; Yin, Z.; Dai, J.; Yin, D.; Liang, J.; et al. Effects of dam construction on biodiversity: A review. J. Clean. Prod. 2019, 221, 480-489. [CrossRef]

55. Collier, M. Dams and Rivers: A Primer on the Downstream Effects of Dams; U.S. Geological Survey Circular, U.S. Geological Survey, Branch of Information Services: Tucson, AZ, USA, 2000.

56. Vörösmarty, C.J.; Meybeck, M.; Fekete, B.; Sharma, K. The potential impact of neo-Castorization on sediment transport by the global network of rivers. In Human Impact on Erosion and Sedimentation; International Association of Hydrological Sciences: Durham, UK, 1997; Volume 245, pp. 261-274.

57. Vörösmarty, C.J.; Meybeck, M.; Fekete, B.; Sharma, K.; Green, P.; Syvitski, J.P.M. Anthropogenic sediment retention: Major global impact from registered river impoundments. Glob. Planet. Chang. 2003, 39, 169-190. [CrossRef]

58. Mahmood, K. Reservoir Sedimentation: Impact, Extent, and Mitigation; World Bank: Washington, DC, USA, 1987.

59. Yoon, Y.N. The state and the perspective of the direct sediment removal methods from reservoirs. Int. J. Sediment Res. 1992, 7, 99-116.

60. Bruk, S. Reservoir sedimentation and sustainable management of water resources-The international perspective. In Proceedings of the International Conference on Reservoir Sedimentation, Fort Collins, CL, USA, 9-13 September 1996.

61. Haddeland, I.; Heinke, J.; Biemans, H.; Eisner, S.; Flörke, M.; Hanasaki, N.; Konzmann, M.; Ludwig, F.; Masaki, Y.; Schewe, J.; et al. Global water resources affected by human interventions and climate change. Proc. Natl. Acad. Sci. USA 2014, 111, 3251-3256. [CrossRef] [PubMed]

62. Blöschl, G.; Hall, J.; Viglione, A.; Perdigão, R.A.P.; Parajka, J.; Merz, B.; Lun, D.; Arheimer, B.; Aronica, G.T.; Bilibashi, A.; et al. Changing climate both increases and decreases European river floods. Nature 2019, 573, 108-111. [CrossRef] [PubMed]

63. Blöschl, G.; Bierkens, M.F.; Chambel, A.; Cudennec, C.; Destouni, G.; Fiori, A.; Kirchner, J.W.; McDonnell, J.J.; Savenije, H.H.; Sivapalan, M.; et al. Twenty-three unsolved problems in hydrology (UPH)-A community perspective. Hydrol. Sci. J. 2019, 64, 1141-1158. [CrossRef]

64. Saam, L.; Mouris, K.; Wieprecht, S.; Haun, S. Three-Dimensional Numerical Modelling of Reservoir Flushing to Obtain Long Term Sediment Equilibrium. In Proceedings of the 38th IAHR World Congress (Panama), Panama City, Panama, 1-6 September 2019; pp. 2364-2371.

65. Annandale, G.W.; Morris, G.L.; Karki, P. Extending the Life of Reservoirs: Sustainable Sediment Management for Dams and Run-of-River Hydropower: Directions in Development-Energy and Mining; World Bank: Washington, DC, USA, 2016.

66. Batuca, D.G.; Jordaan, J.M. Silting and Desilting of Reservoirs; A.A. Balkema: Rotterdam, The Netherlands; Brookfield, VT, USA, 2000.

67. Kondolf, G.M.; Gao, Y.; Annandale, G.W.; Morris, G.L.; Jiang, E.; Zhang, J.; Cao, Y.; Carling, P.; Fu, K.; Guo, Q.; et al. Sustainable sediment management in reservoirs and regulated rivers: Experiences from five continents. Earth Future 2014, 2, 256-280. [CrossRef]

68. Fan, J.; Morris, G.L. Reservoir Sedimentation. II: Reservoir Desiltation and Long-Term Storage Capacity. J. Hydraul. Eng. 1992, 118, 370-384. [CrossRef]

69. Atkinson, E.M. The Feasibility of Flushing Sediment from Reservoirs; HR Wallingford: Wallingford, CT, USA, 1996.

70. Shen, H.W. Flushing sediment through reservoirs. J. Hydraul. Res. 1999, 37, 743-757. [CrossRef] 
71. White, R. Evacuation of Sediments from Reservoirs; Thomas Telford Publishing: Wellingford, UK, 2001. [CrossRef]

72. Haun, S.; Olsen, N.R.B. Three-dimensional numerical modelling of the flushing process of the Kali Gandaki hydropower reservoir. Lakes Reserv. Res. Manag. 2012, 17, 25-33. [CrossRef]

73. Esmaeili, T.; Sumi, T.; Kantoush, S.; Kubota, Y.; Haun, S.; Rüther, N. Three-Dimensional Numerical Study of Free-Flow Sediment Flushing to Increase the Flushing Efficiency: A Case-Study Reservoir in Japan. Water 2017, 9, 900. [CrossRef]

74. Kunz, M.; Mouris, K.; Haun, S.; Karmacharya, S.K.; Rüther, N. Numerical Analysis of Bed Development during Pressure Flushing with Partial Drawdown. In River Flow 2020; CRC Press: London, UK, 2020.

75. Rashid, F.; Zarrati, A.R.; Haun, S. Recent Advances in 3D Numerical Modeling of Reservoir Sedimentation. In Proceedings of the 18th Iranian Hydraulic Conference, Tehran, Iran, 5 February 2020; Faculty of Civil Engineering, University of Tehran: Tehran, Iran, 2020; pp. 5-6.

76. Harb, G.; Haun, S.; Schneider, J.; Olsen, N.R.B. Numerical analysis of synthetic granulate deposition in a physical model study. Int. J. Sediment Res. 2014, 29, 110-117. [CrossRef]

77. Fischer, H.; Pusch, M. Comparison of bacterial production in sediments, epiphyton and the pelagic zone of a lowland river. Freshw. Biol. 2001, 46, 1335-1348. [CrossRef]

78. Flemming, H.C.; Wingender, J. The biofilm matrix. Nat. Rev. Microbiol. 2010, 8, 623-633. [CrossRef] [PubMed]

79. Geesey, G.G.; Mutch, R.; Costerton, J.W.; Green, R.B. Sessile bacteria: An important component of the microbial population in small mountain streams 1. Limnol. Oceanogr. 1978, 23, 1214-1223. [CrossRef]

80. Lozupone, C.A.; Knight, R. Global patterns in bacterial diversity. Proc. Natl. Acad. Sci. USA 2007, 104, 11436-11440. [CrossRef]

81. Stoodley, P.; Sauer, K.; Davies, D.G.; Costerton, J.W. Biofilms as Complex Differentiated Communities. Annu. Rev. Microbiol. 2002, 56, 187-209. [CrossRef]

82. Battin, T.J.; Besemer, K.; Bengtsson, M.M.; Romani, A.M.; Packmann, A.I. The ecology and biogeochemistry of stream biofilms. Nat. Rev. Microbiol. 2016, 14, 251-263. [CrossRef]

83. Gerbersdorf, S.U.; Wieprecht, S. Biostabilization of cohesive sediments: Revisiting the role of abiotic conditions, physiology and diversity of microbes, polymeric secretion, and biofilm architecture. Geobiology 2015, 13, 68-97. [CrossRef]

84. Flemming, H.C. Biofouling and me: My Stockholm syndrome with biofilms. Water Res. 2020, 173, 115576. [CrossRef] [PubMed]

85. Berke, A.P.; Turner, L.; Berg, H.C.; Lauga, E. Hydrodynamic Attraction of Swimming Microorganisms by Surfaces. Phys. Rev. Lett. 2008, 101, 038102. [CrossRef]

86. Tuson, H.H.; Weibel, D.B. Bacteria-surface interactions. Soft Matter 2013, 9, 4368-4380. [CrossRef] [PubMed]

87. Dang, H.; Lovell, C.R. Microbial Surface Colonization and Biofilm Development in Marine Environments. Microbiol. Mol. Biol. Rev. MMBR 2015, 80, 91-138. [CrossRef]

88. Madsen, E.L. Microorganisms and their roles in fundamental biogeochemical cycles. Curr. Opin. Biotechnol. 2011, 22, 456-464. [CrossRef] [PubMed]

89. Nicolella, C.; Zolezzi, M.; Rabino, M.; Furfaro, M.; Rovatti, M. Development of particle-based biofilms for degradation of xenobiotic organic compounds. Water Res. 2005, 39, 2495-2504. [CrossRef]

90. Schultz, P.; Urban, N.R. Effects of bacterial dynamics on organic matter decomposition and nutrient release from sediments: A modeling study. Ecol. Model. 2008, 210, 1-14. [CrossRef]

91. Shannon, M.A.; Bohn, P.W.; Elimelech, M.; Georgiadis, J.G.; Mariñas, B.J.; Mayes, A.M. Science and technology for water purification in the coming decades. Nature 2008, 452, 301-310. [CrossRef]

92. Danovaro, R.; Pusceddu, A. Biodiversity and ecosystem functioning in coastal lagoons: Does microbial diversity play any role? Estuar. Coast. Shelf Sci. 2007, 75, 4-12. [CrossRef]

93. Foshtomi, M.Y.; Braeckman, U.; Derycke, S.; Sapp, M.; van Gansbeke, D.; Sabbe, K.; Willems, A.; Vincx, M.; Vanaverbeke, J. The Link between Microbial Diversity and Nitrogen Cycling in Marine Sediments Is Modulated by Macrofaunal Bioturbation. PLoS ONE 2015, 10, e0130116. [CrossRef]

94. Gilbertson, W.W.; Solan, M.; Prosser, J.I. Differential effects of microorganism-invertebrate interactions on benthic nitrogen cycling. FEMS Microbiol. Ecol. 2012, 82, 11-22. [CrossRef]

95. Jones, S. Goo, glue, and grain binding: Importance of biofilms for diagenesis in sandstones. Geology 2017, 45, 959-960. [CrossRef]

96. Paterson, D.M.; Hope, J.A.; Kenworthy, J.; Biles, C.L.; Gerbersdorf, S.U. Form, function and physics: The ecology of biogenic stabilisation. J. Soils Sediments 2018, 18, 3044-3054. [CrossRef]

97. Fang, H.; Zhao, H.; Shang, Q.; Chen, M. Effect of biofilm on the rheological properties of cohesive sediment. Hydrobiologia 2012, 694, 171-181. [CrossRef]

98. Gibbs, R.J. Effect of natural organic coatings on the coagulation of particles. Environ. Sci. Technol. 1983, 17, 237-240. [CrossRef]

99. Huiming, Z.; Hongwei, F.; Minghong, C. Floc architecture of bioflocculation sediment by ESEM and CLSM. Scanning 2011, 33, 437-445. [CrossRef]

100. Shang, Q.Q.; Fang, H.W.; Zhao, H.M.; He, G.J.; Cui, Z.H. Biofilm effects on size gradation, drag coefficient and settling velocity of sediment particles. Int. J. Sediment Res. 2014, 29, 471-480. [CrossRef]

101. Banasiak, R.; Verhoeven, R.; de Sutter, R.; Tait, S. The erosion behaviour of biologically active sewer sediment deposits: Observations from a laboratory study. Water Res. 2005, 39, 5221-5231. [CrossRef] [PubMed] 
102. Chen, X.D.; Zhang, C.K.; Zhou, Z.; Gong, Z.; Zhou, J.J.; Tao, J.F.; Paterson, D.M.; Feng, Q. Stabilizing Effects of Bacterial Biofilms: EPS Penetration and Redistribution of Bed Stability Down the Sediment Profile. J. Geophys. Res. Biogeosci. 2017, 122, $3113-3125$. [CrossRef]

103. Droppo, I.G.; D’Andrea, L.; Krishnappan, B.G.; Jaskot, C.; Trapp, B.; Basuvaraj, M.; Liss, S.N. Fine-sediment dynamics: Towards an improved understanding of sediment erosion and transport. J. Soils Sediments 2015, 15, 467-479. [CrossRef]

104. Fang, H.; Fazeli, M.; Cheng, W.; Dey, S. Transport of biofilm-coated sediment particles. J. Hydraul. Res. 2016, 54, 631-645. [CrossRef]

105. Fang, H.; Fazeli, M.; Cheng, W.; Huang, L.; Hu, H. Biostabilization and Transport of Cohesive Sediment Deposits in the Three Gorges Reservoir. PLoS ONE 2015, 10, e0142673. [CrossRef] [PubMed]

106. Fang, H.W.; Lai, H.J.; Cheng, W.; Huang, L.; He, G.J. Modeling sediment transport with an integrated view of the biofilm effects. Water Resour. Res. 2017, 53, 7536-7557. [CrossRef]

107. Malarkey, J.; Baas, J.H.; Hope, J.A.; Aspden, R.J.; Parsons, D.R.; Peakall, J.; Paterson, D.M.; Schindler, R.J.; Ye, L.; Lichtman, I.D.; et al. The pervasive role of biological cohesion in bedform development. Nat. Commun. 2015, 6. [CrossRef]

108. Righetti, M.; Lucarelli, C. Resuspension phenomena of benthic sediments: The role of cohesion and biological adhesion. River Res. Appl. 2010, 26, 404-413. [CrossRef]

109. Vignaga, E.; Sloan, D.M.; Luo, X.; Haynes, H.; Phoenix, V.R.; Sloan, W.T. Erosion of biofilm-bound fluvial sediments. Nat. Geosci. 2013, 6, 770-774. [CrossRef]

110. Burns, A.; Ryder, D.S. Potential for biofilms as biological indicators in Australian riverine systems. Ecol. Manag. Restor. 2001, 2, 53-64. [CrossRef]

111. Förstner, U.; Heise, S.; Schwartz, R.; Westrich, B.; Ahlf, W. Historical Contaminated Sediments and Soils at the River Basin Scale. J. Soils Sediments 2004, 4, 247. [CrossRef]

112. de Brouwer, J.; Wolfstein, K.; Ruddy, G.K.; Jones, T.; Stal, L.J. Biogenic Stabilization of Intertidal Sediments: The Importance of Extracellular Polymeric Substances Produced by Benthic Diatoms. Microb. Ecol. 2005, 49, 501-512. [CrossRef] [PubMed]

113. Passarelli, C.; Olivier, F.; Paterson, D.M.; Meziane, T.; Hubas, C. Organisms as cooperative ecosystem engineers in intertidal flats. J. Sea Res. 2014, 92, 92-101. [CrossRef]

114. Gerbersdorf, S.U.; Koca, K.; de Beer, D.; Chennu, A.; Noss, C.; Risse-Buhl, U.; Weitere, M.; Eiff, O.; Wagner, M.; Aberle, J.; et al. Exploring flow-biofilm-sediment interactions: Assessment of current status and future challenges. Water Res. 2020, 185, 116182. [CrossRef]

115. Dietrich, D.R.; Fischer, A.; Michel, C.; Hoeger, S.J. Toxin mixture in cyanobacterial blooms-A critical comparison of reality with current procedures employed in human health risk assessment. In Cyanobacterial Harmful Algal Blooms: State of the Science and Research Needs; Hudnell, H.K., Ed.; Advances in Experimental Medicine and Biology; Springer: New York, NY, USA, 2008; pp. 885-912. [CrossRef]

116. O'Neil, J.M.; Davis, T.W.; Burford, M.A.; Gobler, C.J. The rise of harmful cyanobacteria blooms: The potential roles of eutrophication and climate change. Harmful Algae 2012, 14, 313-334. [CrossRef]

117. Paerl, H.W.; Huisman, J. Blooms Like It Hot. Science 2008, 320, 57-58. [CrossRef]

118. Quiblier, C.; Wood, S.; Echenique-Subiabre, I.; Heath, M.; Villeneuve, A.; Humbert, J.F. A review of current knowledge on toxic benthic freshwater cyanobacteria - Ecology, toxin production and risk management. Water Res. 2013, 47, 5464-5479. [CrossRef]

119. Callieri, C.; Bertoni, R.; Contesini, M.; Bertoni, F. Lake Level Fluctuations Boost Toxic Cyanobacterial "Oligotrophic Blooms". PLoS ONE 2014, 9, e109526. [CrossRef] [PubMed]

120. Ernst, B.; Hoeger, S.J.; O’Brien, E.; Dietrich, D.R. Abundance and toxicity of Planktothrix rubescens in the pre-alpine Lake Ammersee, Germany. Harmful Algae 2009, 8, 329-342. [CrossRef]

121. Posch, T.; Köster, O.; Salcher, M.M.; Pernthaler, J. Harmful filamentous cyanobacteria favoured by reduced water turnover with lake warming. Nat. Clim. Chang. 2012, 2, 809-813. [CrossRef]

122. Salmaso, N. Long-term phytoplankton community changes in a deep subalpine lake: Responses to nutrient availability and climatic fluctuations. Freshw. Biol. 2010, 55, 825-846. [CrossRef]

123. Salmaso, N.; Buzzi, F.; Garibaldi, L.; Morabito, G.; Simona, M. Effects of nutrient availability and temperature on phytoplankton development: A case study from large lakes south of the Alps. Aquat. Sci. 2012, 74, 555-570. [CrossRef]

124. Dolman, A.M.; Rücker, J.; Pick, F.R.; Fastner, J.; Rohrlack, T.; Mischke, U.; Wiedner, C. Cyanobacteria and Cyanotoxins: The Influence of Nitrogen versus Phosphorus. PLoS ONE 2012, 7, e38757. [CrossRef] [PubMed]

125. Paerl, H.W.; Otten, T.G. Harmful Cyanobacterial Blooms: Causes, Consequences, and Controls. Microb. Ecol. 2013, 65, 995-1010. [CrossRef] [PubMed]

126. Chorus, I.; Bartram, J. Toxic Cyanobacteria in Water: A Guide to Their Public Health Consequences, Monitoring and Management; World Health Organization: New York, NY, USA, 1999.

127. Ibelings, B.W.; Backer, L.C.; Kardinaal, W.E.A.; Chorus, I. Current approaches to cyanotoxin risk assessment and risk management around the globe. Harmful Algae 2014, 40, 63-74. [CrossRef]

128. Paerl, H.W.; Gardner, W.S.; Havens, K.E.; Joyner, A.R.; McCarthy, M.J.; Newell, S.E.; Qin, B.; Scott, J.T. Mitigating cyanobacterial harmful algal blooms in aquatic ecosystems impacted by climate change and anthropogenic nutrients. Harmful Algae 2016, 54, 213-222. [CrossRef] 
129. Chorus, I. Current Approaches to Cyanotoxin Risk Assessment, Risk Management and Regulations in Different Countries; Umweltbundesamt: Dessau-Roßlau, Germany. Available online: https://www.umweltbundesamt.de/publikationen/current-approaches-tocyanotoxin-risk-assessment-0 (accessed on 14 April 2021).

130. Bullerjahn, G.S.; McKay, R.M.; Davis, T.W.; Baker, D.B.; Boyer, G.L.; D’Anglada, L.V.; Doucette, G.J.; Ho, J.C.; Irwin, E.G.; Kling, C.L.; et al. Global solutions to regional problems: Collecting global expertise to address the problem of harmful cyanobacterial blooms. A Lake Erie case study. Harmful Algae 2016, 54, 223-238. [CrossRef]

131. Barros, N.; Cole, J.J.; Tranvik, L.J.; Prairie, Y.T.; Bastviken, D.; Huszar, V.L.M.; del Giorgio, P.; Roland, F. Carbon emission from hydroelectric reservoirs linked to reservoir age and latitude. Nat. Geosci. 2011, 4, 593-596. [CrossRef]

132. Beaulieu, J.J.; Smolenski, R.L.; Nietch, C.T.; Townsend-Small, A.; Elovitz, M.S. High Methane Emissions from a Midlatitude Reservoir Draining an Agricultural Watershed. Environ. Sci. Technol. 2014, 48, 11100-11108. [CrossRef]

133. Hertwich, E.G. Addressing Biogenic Greenhouse Gas Emissions from Hydropower in LCA. Environ. Sci. Technol. 2013, 47, 9604-9611. [CrossRef]

134. Luyssaert, S.; Abril, G.; Andres, R.; Bastviken, D.; Bellassen, V.; Bergamaschi, P.; Bousquet, P.; Chevallier, F.; Ciais, P.; Corazza, M.; et al. The European land and inland water $\mathrm{CO}_{2}, \mathrm{CO}, \mathrm{CH}_{4}$ and $\mathrm{N}_{2} \mathrm{O}$ balance between 2001 and 2005. Biogeosciences 2012, 9, 3357-3380. [CrossRef]

135. Raymond, P.A.; Hartmann, J.; Lauerwald, R.; Sobek, S.; McDonald, C.; Hoover, M.; Butman, D.; Striegl, R.; Mayorga, E.; Humborg, C.; et al. Global carbon dioxide emissions from inland waters. Nature 2013, 503, 355-359. [CrossRef] [PubMed]

136. Deemer, B.R.; Harrison, J.A.; Li, S.; Beaulieu, J.J.; DelSontro, T.; Barros, N.; Bezerra-Neto, J.F.; Powers, S.M.; dos Santos, M.A.; Vonk, J.A. Greenhouse Gas Emissions from Reservoir Water Surfaces: A New Global Synthesis. BioScience 2016, 66, 949-964. [CrossRef] [PubMed]

137. Engle, D.; Melack, J.M. Methane emissions from an Amazon floodplain lake: Enhanced release during episodic mixing and during falling water. Biogeochemistry 2000, 51, 71-90. [CrossRef]

138. Deborde, J.; Anschutz, P.; Guérin, F.; Poirier, D.; Marty, D.; Boucher, G.; Thouzeau, G.; Canton, M.; Abril, G. Methane sources, sinks and fluxes in a temperate tidal Lagoon: The Arcachon lagoon (SW France). Estuar. Coast. Shelf Sci. 2010, 89, 256-266. [CrossRef]

139. Varadharajan, C.; Hemond, H.F. Time-series analysis of high-resolution ebullition fluxes from a stratified, freshwater lake. J. Geophys. Res. Biogeosciences 2012, 117. [CrossRef]

140. Maeck, A.; Hofmann, H.; Lorke, A. Pumping methane out of aquatic sediments - ebullition forcing mechanisms in an impounded river. Biogeosciences 2014, 11, 2925-2938. [CrossRef]

141. Harrison, J.A.; Deemer, B.R.; Birchfield, M.K.; O’Malley, M.T. Reservoir Water-Level Drawdowns Accelerate and Amplify Methane Emission. Environ. Sci. Technol. 2017, 51, 1267-1277. [CrossRef]

142. Encinas Fernández, J.; Peeters, F.; Hofmann, H. Importance of the Autumn Overturn and Anoxic Conditions in the Hypolimnion for the Annual Methane Emissions from a Temperate Lake. Environ. Sci. Technol. 2014, 48, 7297-7304. [CrossRef]

143. Kornijów, R. Controversies around dam reservoirs: Benefits, costs and future. Ecohydrol. Hydrobiol. 2009, 9, 141-148. [CrossRef]

144. Siegmund-Schultze, M.; do Carmo Sobral, M.; de Moraes, A.; Márcia, M.G.; Almeida-Cortez, J.S.; Azevedo, J.R.G.; Candeias, A.L.; Cierjacks, A.; Gomes, E.T.A.; Gunkel, G.; et al. The legacy of large dams and their effects on the water-land nexus. Reg. Environ. Chang. 2018, 18, 1883-1888. [CrossRef]

145. Cernea, M.M. Hydropower Dams and Social Impacts: A Sociological Perspective; Environment Department, World Bank: New York, NY, USA, 1997.

146. Costa, A.; Caldas, J.C.; Coelho, R.; Ferreiro, M.d.F.; Gonçalves, V. The Building of a Dam: Value Conflicts in Public DecisionMaking. Environ. Values 2016, 25, 215-234. [CrossRef]

147. de Faria, F.A.; Davis, A.; Severnini, E.; Jaramillo, P. The local socio-economic impacts of large hydropower plant development in a developing country. Energy Econ. 2017, 67, 533-544. [CrossRef]

148. Ansar, A.; Flyvbjerg, B.; Budzier, A.; Lunn, D. Should we build more large dams? The actual costs of hydropower megaproject development. Energy Policy 2014, 69, 43-56. [CrossRef]

149. Schrenk-Bergt, C.; Krause, D.; Prawitt, O.; Lewandowski, J.; Steinberg, C.E.W. Eutrophication problems and their potential solutions in the artificial shallow lake Altmühlsee (Germany). Stud. Quarternaria 2004, 21, 73-86. [CrossRef]

150. Pahl-Wostl, C. Governance of the water-energy-food security nexus: A multi-level coordination challenge. Environ. Sci. Policy 2019, 92, 356-367. [CrossRef]

151. Siegwald, L.; de Jong, C. Anthropogenic Impacts on Water Quality in a Small, Forested Mountain Catchment: A Case Study of the Seebächle, Black Forest, Southern Germany. Sustainability 2020, 12, 9022. [CrossRef]

152. Das Bundesministerium für Umwelt, Naturschutz und Nukleare Sicherheit, Umweltbundesamt; Die WasserrahmenrichtlinieDeutschlands Gewässer: Berlin, Germany, 2015.

153. Aguiar, F.C.; Martins, M.J.; Silva, P.C.; Fernandes, M.R. Riverscapes downstream of hydropower dams: Effects of altered flows and historical land-use change. Landsc. Urban Plan. 2016, 153, 83-98. [CrossRef]

154. Dittmann, R.; Froehlich, F.; Pohl, R.; Ostrowski, M. Optimum multi-objective reservoir operation with emphasis on flood control and ecology. Nat. Hazards Earth Syst. Sci. 2009, 9, 1973-1980. [CrossRef] 
155. European Parliament; The European Council. Directive 2000/60/EC of the European Parliament and of the Council of 23 October 2000 Establishing a Framework for Community Action in the Field of Water Policy: EU Water Framework Directive, 22.12.2000; Official Journal L 327, 22/12/2000 P. 0001 - 0073; European Union: Strasbourg, France, 2000.

156. Marshall, A.C.; Duram, L.A. Factors influencing local stakeholders' perceptions of Tisza River Basin management: The role of employment sector and education. Environ. Sci. Policy 2017, 77, 69-76. [CrossRef]

157. Nguyen, H.T.; Pham, T.H.; Lobry de Bruyn, L. Impact of Hydroelectric Dam Development and Resettlement on the Natural and Social Capital of Rural Livelihoods in Bo Hon Village in Central Vietnam. Sustainability 2017, 9, 1422. [CrossRef]

158. Bakken, T.H.; Sundt, H.; Ruud, A.; Harby, A. Development of Small Versus Large Hydropower in Norway- Comparison of Environmental Impacts. Energy Procedia 2012, 20, 185-199. [CrossRef]

159. Bakken, T.H.; Aase, A.G.; Hagen, D.; Sundt, H.; Barton, D.N.; Lujala, P. Demonstrating a new framework for the comparison of environmental impacts from small- and large-scale hydropower and wind power projects. J. Environ. Manag. 2014, 140, 93-101. [CrossRef]

160. Idsø, J. Small Scale Hydroelectric Power Plants in Norway. Some Microeconomic and Environmental Considerations. Sustainability 2017, 9, 1117. [CrossRef]

161. Tilt, B.; Gerkey, D. Dams and population displacement on China's Upper Mekong River: Implications for social capital and social-ecological resilience. Glob. Environ. Chang. 2016, 36, 153-162. [CrossRef]

162. Sovacool, B.K.; Walter, G. Major hydropower states, sustainable development, and energy security: Insights from a preliminary cross-comparative assessment. Energy 2018, 142, 1074-1082. [CrossRef]

163. Giesecke, J.; Mosonyi, E. Wasserkraftanlagen: Planung, Bau und Betrieb, 5th ed.; Springer: Berlin/Heidelberg, Germany, 2009. [CrossRef]

164. Hanson, T.R.; Hatch, L.U.; Clonts, H.C. Reservoir Water Level Impacts on Recreation, Property, and Nonuser Values1. JAWRA J. Am. Water Resour. Assoc. 2002, 38, 1007-1018. [CrossRef]

165. Godde, D.; Engels, K.; Schmid, S.; Achatz, R.; Haupt, O.; Beer, C.; Höller, S.; Jaberg, H.; Miller, B.; Heigerth, G.; et al. Pumpspeicherkraftwerke. In Heimerl (Hg.) 2015-Wasserkraftprojekte; Springer: Wiesbaden, Germany, 2015; Volume Band 2, pp. 277-354.

166. Daus, M.; Koberger, K.; Gnutzmann, N.; Hertrich, T.; Glaser, R. Transferring Water While Transforming Landscape: New Societal Implications, Perceptions and Challenges of Management in the Reservoir System Franconian Lake District. Water 2019, 11, 2469. [CrossRef]

167. Kleinhenz, A.; Koenig, A. Home ranges and movements of resident graylag geese (Anser anser) in breeding and winter habitats in Bavaria, South Germany. PLoS ONE 2018, 13, e0202443. [CrossRef] [PubMed]

168. Bundesministerium der Justiz und für Verbraucherschutz. Gesetz zur Ordnung des Wasserhaushalts (Wasserhaushaltsgesetz): WHG, 15.07.2020; BMJV: Berlin, Germany, 2020.

169. Bundesministerium der Justiz und für Verbraucherschutz. Verordnung über die Qualität von Wasser für den menschlichen Gebrauch (Trinkwasserverordnung): TrinkwV, 21.05.2001; BMJV: Berlin, Germany, 2001.

170. Jiménez Cisneros, B.E.; Oki, T.; Arnell, N.W.; Benito, G.; Cogley, J.G.; Döll, P.; Jiang, T.; Mwakalila, S.S. Freshwater resources. In Climate Change 2014: Impacts, Adaptation, and Vulnerability. Part A: Global and Sectoral Aspects. Contribution of Working Group II to the Fifth Assessment Report of the Intergovernmental Panel of Climate Change; Field, C.B., Barros, V.R., Dokken, D.J., Mach, K.J., Mastrandrea, M.D., Bilir, T.E., Chatterjee, M., Ebi, K.L., Estrada, Y.O., Genova, R.C., et al., Eds.; Cambridge University Press: Cambridge, UK; New York, NY, USA, 2014; pp. 229-269.

171. The European Parliament; The Council of the European Union. Directive 2007/60/EC og the European Parliament and of the Council of 23 October 2007 on the Assessment and Management of Flood Risks, 06.11.2007; Europian Union: Strasbourg, France, 2007.

172. Borchardt, D.; Bogardi, J.J.; Ibisch, R.B. Integrated Water Resources Management: Concept, Research and Implementation; Springer International Publishing: Cham, Switzerland, 2016. [CrossRef]

173. Bhaduri, A.; Bogardi, J.; Siddiqi, A.; Voigt, H.; Vörösmarty, C.; Pahl-Wostl, C.; Bunn, S.E.; Shrivastava, P.; Lawford, R.; Foster, S.; et al. Achieving Sustainable Development Goals from a Water Perspective. Front. Environ. Sci. 2016, 4, 211. [CrossRef]

174. Bogardi, J.J.; Dudgeon, D.; Lawford, R.; Flinkerbusch, E.; Meyn, A.; Pahl-Wostl, C.; Vielhauer, K.; Vörösmarty, C. Water security for a planet under pressure: Interconnected challenges of a changing world call for sustainable solutions. Curr. Opin. Environ. Sustain. 2012, 4, 35-43. [CrossRef]

175. Tilt, B.; Braun, Y.; He, D. Social impacts of large dam projects: A comparison of international case studies and implications for best practice. J. Environ. Manag. 2009, 90, S249-S257. [CrossRef] [PubMed]

176. Zal, N.; Whalley, C.; Christiansen, T.; Kristensen, P.; Néry, F. European Waters: Assessment of Status and Pressures 2018; Vol. no 2018,7, EEA Report; Publications Office of the European Union: Luxembourg, 2018. [CrossRef] 